OECDpublishing

\title{
MULTINATIONAL ENTERPRISES AND INTANGIBLE CAPITAL
}

OECD SCIENCE, TECHNOLOGY AND INDUSTRY POLICY PAPERS

September 2021 No. 118 
This paper was approved and declassified by written procedure by the Working Party on Industry Analysis (WPIA) on 2 April 2021 and prepared for publication by the OECD Secretariat.

Note to Delegations:

This document is also available on O.N.E. under the reference code:

This document, as well as any data and any map included herein, are without prejudice to the status of or sovereignty over any territory, to the delimitation of international frontiers and boundaries and to the name of any territory, city or area.

(C) OECD 2021

The use of this work, whether digital or print, is governed by the Terms and Conditions to be found at http://www.oecd.org/termsandconditions. 


\section{Multinational Enterprises and Intangible Capital}

Charles Cadestin (TAD), Alexander Jaax (TAD), Sébastien Miroudot (TAD) and Carmen Zürcher (STI)

OECD

This paper provides new evidence on the role of intangible capital in global value chains (GVCS) by focusing on the role of multinational enterprises (MNEs) and their foreign affiliates in value capture through intangible assets. Industry-level data suggest that foreign affiliates of MNEs generate more income through intangible capital than domesticowned firms. Intangible returns from foreign affiliates are found both in the host economy and in foreign-owned firms in other countries participating in the GVC. Some heterogeneity is observed across GVCs with returns to intangible capital of foreign-owned firms concentrated in key manufacturing (chemicals including pharmaceuticals, food products, ICT and electronics, and motor vehicles) and services GVCs (finance and insurance, other business services, wholesale and retail, and telecoms). Five case studies (Adidas, AstraZeneca, Rocket Internet, Starbucks and Tata Consultancy Services) complement the analysis by looking at the role of intangible capital in the GVC of specific MNEs.

Keywords: global value chains; intangible capital; factor income; multinational enterprises; foreign affiliates

Acknowledgements: This report was prepared by Charles Cadestin, Alexander Jaax, Sébastien Miroudot and Carmen Zürcher of the OECD as part of a joint project by the Directorate for Financial and Enterprise Affairs (DAF), Directorate for Science, Technology and Innovation (STI) and Trade and Agriculture Directorate (TAD). The authors are grateful to John Drummond, Hermann Garden, Daniel Hanssler, Nicolas Hincelin and Colin Webb for useful comments and suggestions. This paper also benefitted from discussions in the Working Party on Industry Analysis (WPIA), which agreed to make it more widely available through declassification, as well as discussions in the Working Party of the Trade Committee. 


\section{Table of contents}

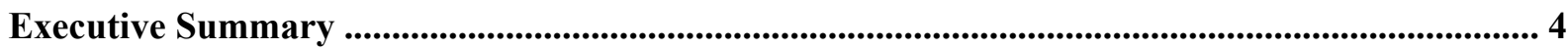

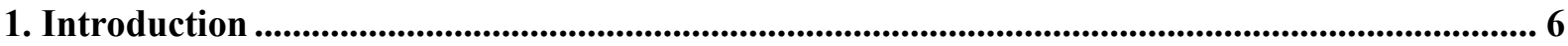

2. Returns to intangible capital along the value chain for domestic-owned and foreign-owned

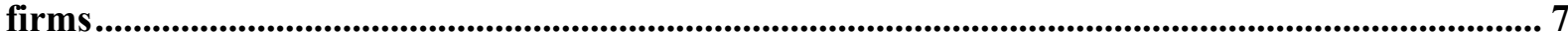

3. How MNEs build competitiveness through intangible assets: case studies.................................. 14

4. The "ABCs" of GVC-oriented policies: further policy implications related to MNEs .............. 32

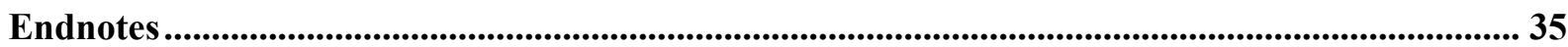

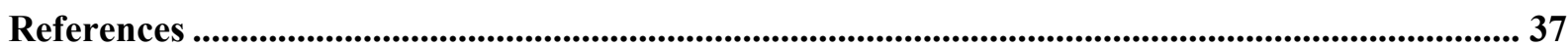

Annex A. Methodology for the estimation of returns to intangible capital in GVCs and their

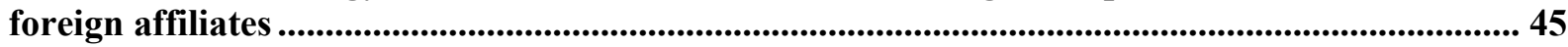

Annex B. Methodology to distinguish purely domestic production from international production in returns to intangible capital ...................................................................................................... 52

\section{Tables}

Table 3.1. Rocket Internet's income statement $\quad 25$

Table A.1. Sources for the adjustment of labour shares 46

Table A.2. Ratios of factor intensity between foreign affiliates and domestic-owned firms 48

\section{Figures}

Figure 2.1. Factor income shares, domestic-owned vs. foreign-owned firms $\quad 8$

Figure 2.2. Breakdown of world returns to intangible capital in GVCs, 2016

Figure 2.3. World returns to intangible capital by GVC final product, $2016 \quad 11$

Figure 2.4. Breakdown of returns to intangible capital by GVC final product, 2016

Figure 2.5. Share of world gross value added and world returns to intangible capital, by country group 14

Figure 3.1. AstraZeneca's blockbuster products from 2000 to $2019 \quad 20$

$\begin{array}{lr}\text { Figure 3.2. AstraZeneca's network of affiliates } & 22\end{array}$

$\begin{array}{lr}\text { Figure 3.3. Rocket Internet's main businesses } & 25\end{array}$

$\begin{array}{lr}\text { Figure 3.4. TCS' network of foreign affiliates } & 30\end{array}$ 


\section{Executive Summary}

This paper provides new evidence on the role of intangible capital in global value chains (GVCs) by focusing on the role of multinational enterprises (MNEs) and their foreign affiliates in value capture through intangible assets. It also provides a more concrete sense of the role played by intangible capital in MNE strategies through five case studies.

Building on OECD data collected to assess returns to intangible capital in GVCs and combining them with the OECD Analytical AMNE database, the report finds that foreign affiliates of MNEs generate more income through intangible assets than domestic-owned firms. This is consistent with the choice of a FDI strategy to keep knowledge within the boundaries of multinational firms and the fact that foreign affiliates benefit from the accumulation of intangible capital in their parent companies and their network of affiliates. The production of foreign-owned firms is more intensive in intangible capital and less intensive in labour.

A second finding is that intangible returns generated by foreign affiliates in GVCs are both in the domestic economy and through foreign-owned firms in other countries participating in the value chain. In manufacturing GVCs, foreign affiliates account for $23 \%$ of purely domestic returns to intangible capital while their share in gross value added is only $16 \%$. The share of foreign affiliates is higher (30\%) in returns to intangible capital generated through international production (i.e. in the non-domestic part of the value chain), but more in line with their share in gross value added (24\%). Most of returns to intangible capital are in services GVCs ( $42 \%$ ) where the prevalence of foreign-owned firms is lower for domestic production (15\%) but at a similar level for the international part of the value chain $(27 \%)$.

Some heterogeneity is observed across GVCs with returns to intangible capital of foreignowned firms concentrated in key manufacturing GVCs (chemicals including pharmaceuticals, food products, ICT \& electronics and motor vehicles) and services GVCs (finance \& insurance, other business services, wholesale \& retail and telecoms). Across countries, middle-income economies have increased their world share of returns derived from intangible capital but MNEs of high-income economies continue to account for most of returns going to foreign affiliates.

Intangible capital encompasses a wide range of assets that have no physical or financial embodiment. To give a more concrete view of how they are accumulated in MNEs and contribute to the organisation of the network of foreign affiliates, the report introduces five case studies. Adidas, a provider of sports shoes, clothing and accessories, is a good example of a lead firm in a buyer-driven GVC with a strategy centred on the outsourcing of production and strong design and distribution capabilities. It controls the value chain through intangible assets and relies on foreign affiliates at the distribution stage where it captures value. In the pharmaceutical industry, AstraZeneca illustrates how value is also captured through intangible assets in a producer-driven value chain. In an industry facing decreasing returns on $R \& D$ investments, the company increasingly engage in collaboration agreements and mergers \& acquisitions (M\&A) deals to remain competitive, with its foreign affiliates mostly found at the beginning of the value chain.

In the digital industry, Rocket Internet illustrates a new type of strategy based on the replication of innovative business models that have proven successful in some markets but have not yet arrived in others. The company has a portfolio of internet retail businesses that start as affiliates and are then sold when being successful. Rocket Internet has been described as a 'start-up studio'. In a more traditional industry, Starbucks is a coffee bean 
retailer that turned into the largest coffeehouse chain in the world through a strategy focused on improving the experience of its customers. It operates most of its stores directly (as affiliates) and has developed a high degree of control over its value chain to ensure the quality and homogeneity of its products.

Lastly, Tata Consultancy Services is an IT consultancy company from an emerging economy. It operates through a global delivery model where foreign affiliates combine the benefits of geographical proximity to customers with location-specific comparative advantages. Together, these companies illustrate the different roles played by foreign affiliates in MNEs and how they generate income through intangible capital.

In a previous OECD report, it was argued that the position of intangibles at the heart of GVCs and their rising value capture imply that governments should consider three types of GVC-oriented policies to stimulate the production of intangibles: Attractiveness policies that aim to strengthen the appeal of a location for GVC activities; place-based Buzz policies that intend to internally strengthen the local production and innovation ecosystem; and international Connectedness policies that aspire to strengthen the local ecosystem by creating connections to other locations.

This report complements the "ABCs" of GVC-oriented policies by emphasising that a high share of intangible capital returns comes from foreign-owned firms. As highlighted in the literature on FDI spillovers, countries can benefit from the accumulation of intangible capital in foreign affiliates, either when foreign-owned firms are established in their domestic economy or when foreign-owned firms are part of their international supply chains. Therefore, attractiveness policies should target foreign firms and address the regulatory barriers that can discourage them from operating in the domestic economy. Spillovers are however not automatic and buzz policies can help countries to develop the required "absorptive capacity" that will allow domestic firms to participate in GVCs. While buzz policies can strengthen the innovation capacity of domestic firms, including when foreign-owned, connectedness policies are complementary to allow knowledge spillovers through the international value chain and through interactions with global firms.

Finally, as there is a reorganisation of GVCs that may be accelerated by COVID-19, attractiveness, buzz and connectedness policies are particularly important for countries to attract or to maintain in their economy intangible-intensive activities. 


\section{Introduction}

This paper complements previous OECD analysis on the role of intangible capital in global value chains (GVCs) (Alsamawi et al., 2020 ${ }_{[1]}$ ) and further develops the policy implications related to the role of intangible assets in value capture (Van Assche, 2020 [2]). In particular, it focuses on the way both parent and host countries benefit from the accumulation of intangible capital in multinational enterprises (MNEs) and investigates the policies that can facilitate the diffusion of knowledge in GVCs to increase these benefits and ensure that they are fairly shared across countries.

Intangible capital encompasses a wide range of knowledge-based assets that lack a physical embodiment (Lev, 2001 ${ }_{[3]}$; OECD, 2013 $3_{[4]}$ ). Intangibles are frequently grouped into three categories (Corrado, Hulten and Sichel, 2005 $5_{[5]}$ ): computerised information (such as datasets on consumer preferences), innovative property (e.g. a new financial product), and economic competencies (e.g. a strategy to improve information sharing between a multinational enterprise's subsidiaries and the headquarters). These intangible assets play an important role in value capture in GVCs (Dedrick, Kraemer and Linden, 2010[6]). The 'smile curve' identified in the GVC literature (Mudambi, 2007 $\left[7_{[]}\right.$) -where high value-added activities are at the beginning and the end of the value chain - can be explained by the accumulation of intangible capital, such as R\&D upstream, or brands and data on consumers downstream. Core manufacturing activities in the middle of the value chain generate less value added per unit of output (Stöllinger, 2021 ${ }_{[8]}$ ) in industries that are less knowledge-intensive (Mudambi, 2008 ${ }_{[9]}$ ).

Multinational production is also related to intangible capital. The early literature on MNEs does not refer to intangible assets but explains that MNEs can produce and sell their products in foreign countries because they possess firm-specific advantages such as superior technology or brand names that give them an advantage over local firms (Buckley and Casson, 1976 ${ }_{[10]}$; Caves, $\left.1971_{[11]}\right)$. Firm-specific advantages are built mostly through investment in intangible capital. Moreover, as emphasised by the internalisation theory, firms become MNEs and create affiliates in foreign countries to be able to transfer the knowledge that underpins these firm-specific advantages to entities that they control, so that this knowledge remains within the firm (Rugman, 1981 ${ }_{[12]}$ ). These intangible assets are in some cases complementary to assets available in the host economy (Hennart, 2009 [13]).

The knowledge-based perspective of the firm also suggests that MNEs are organised to internally exploit accumulated proprietary knowledge or intellectual property (Kogut and Zander, 1992 $\left.{ }_{[14]}\right)$. Transfers and re-combination of knowledge occur more efficiently within MNEs, especially when it comes to tacit knowledge (Kogut and Zander, 1993 ${ }_{[15]}$ ). The less codifiable and the harder it is to teach a technology, the more costly it is to operate with third parties. Therefore, firms with tacit knowledge prefer to serve foreign markets through multinational production. As opposed to exports, multinational production allows them to accumulate knowledge in these foreign countries as well. This knowledge is also transferred and recombined through the MNE network. Acquiring knowledge can also be the motivation for foreign direct investment (FDI) (Cantwell, $\left.1989_{[16]}\right)$.

With respect to subsidiaries dedicated to R\&D, MNEs often create "location portfolios" in order to tap into place-specific knowledge pools (Cantwell, 2009 ${ }_{[17]}$; Meyer, Mudambi and Narula, $\left.2011_{[18]}\right)$. These location strategies seek to expand the set of knowledge assets that the MNE can combine. At the same time, such location portfolios can help to reduce risks associated with overreliance on a narrow set of technologies. Subsidiaries acting as "listening posts" (Maskell, 2014 $4_{[19]}$ ) focused on the monitoring of new technological trends may limit the risk of a deterioration of the MNE's position relative to the technological frontier. 
However, the performance and profitability of foreign affiliates often comes from the intangible assets of their parent companies (Villalonga, 2004 [20]; Contractor, Yang and Gaur, 2016 $6_{[21]}$ ). These assets include proprietary knowledge and intellectual property (such as patents or brands) but also organisational routines, production processes, as well as the firm's relationships and reputation. Subsidiaries can use these intangible assets without fully supporting their costs and have thus an advantage both in terms of competitiveness and profitability. Yet, there are factors that prevent or limit the ability of affiliates to benefit from intangible assets accumulated in their parent firms, such as the technological distance, the local intellectual property protection (IPP) regime, institutional barriers (including limitations on foreign ownership) or cultural differences. The assimilation of knowledge depends on the 'absorptive capacity' (Cohen and Levinthal, 1990 ${ }_{[22]}$ ) of affiliates and this concept also plays a role in knowledge diffusion across countries within GVCs (Pietrobelli and Rabellotti, 2011 $\left.1_{[23]}\right)$.

Recently, the emphasis has also been put on the role of fiscal optimisation strategies in explaining the structure of MNE networks. Firms often shift profit across countries by relying on payments for intellectual property (Grubert, 2003 [24]; Dischinger and Riedel, $\left.2011_{[25]}\right)$. For example, the subsidiary of a MNE in a location where corporate taxes are high can pay royalties to a subsidiary located in a low tax jurisdiction for the use of its brand or technology. The income generated is then transferred back to the parent company.

Finally, with COVID-19, the "real option" perspective can also be found relevant in looking at the role of intangible capital in MNE networks. According to real option theory, MNEs operate in different countries to hedge risks and to be able to shift value-added activities across locations in response to changes in costs and market conditions (Kogut and Kulatilaka, 1994[26]). In an uncertain environment, MNEs might be encouraged to add redundancy in their network of foreign affiliates. They might also decide to divest when the uncertainty is greater in some locations (Belderbos and Zou, 2009 [27]). Investment in intangible capital provides firms with switching options and contributes to managerial flexibility (Sudarsanam, Sorwar and Marr, 2006 $[28]$ ). It may also play a role in the reorganisation of GVCs post-COVID-19.

The rest of the paper is organised as follows. Section 2 provides insights from a new industry-level dataset on returns to intangible capital in GVCs distinguishing foreignowned firms (i.e. foreign affiliates of MNEs) from domestic-owned firms. Section 3 illustrates with case studies how intangible capital explains the organisation and the income generated by MNEs in GVCs. Section 4 concludes with some policy implications.

\section{Returns to intangible capital along the value chain for domestic-owned and foreign- owned firms}

Intangible capital accounts for about $27 \%$ of income in manufacturing GVCs and $22 \%$ of income in services GVCs in OECD Members (Alsamawi et al., 2020 $0_{[1]}$ ). A significant share of this income is captured in the distribution stage (i.e. at the end of the value chain), especially in buyer-driven GVCs (e.g. textiles and apparel). In producer-driven value chains (e.g. motor vehicles), more income is captured in the final stage of production. Over time, returns to intangible capital have increased but unevenly across production stages and industries, pointing to specific trends in different GVCs.

In this section, we revisit the evidence on returns to intangible capital in GVCs by introducing data that allow us to distinguish foreign-owned firms from domestic-owned firms. These data were obtained by combining the information on factor income previously collected at the industry level with the OECD Analytical AMNE database where we have 
estimates of output and value added according to the ownership of firms. Differences in the accumulation of intangible capital across domestic and foreign-owned firms are captured through estimates derived from firm-level data. Further information on the methodology can be found in Annex A. It should be stressed that results are rough estimates that we use to describe the broad picture at the industry level. These results cannot capture the heterogeneity within industries, which is the reason why the next section focuses on case studies. It is also important to note that due to the intangible nature of the assets, every methodology measuring returns to intangible capital brings its own caveats. This paper relies on a residual approach to measure returns to intangible capital which is discussed in detail in Alsamawi et al. $\left(2020_{[1]}\right)$ with robustness checks on the sensitivity of results to data sources and underlying assumptions.

\subsection{Foreign-owned firms generate more returns through intangible capital}

As highlighted in the introduction, intangible capital is one of the main drivers of multinational production. MNEs serve markets or source inputs through foreign affiliates in order to keep knowledge within the boundaries of the firm and these affiliates benefit from the intangible capital accumulated in their parent company. We thus expect foreignowned firms to derive a higher share of their value added from intangible capital. We empirically observe this result when comparing the average factor income shares of foreign-owned firms and domestic-owned firms (Figure 2.1).

\section{Figure 2.1. Factor income shares, domestic-owned vs. foreign-owned firms}

Average income shares for all manufacturing and commercial services GVCs, 2015

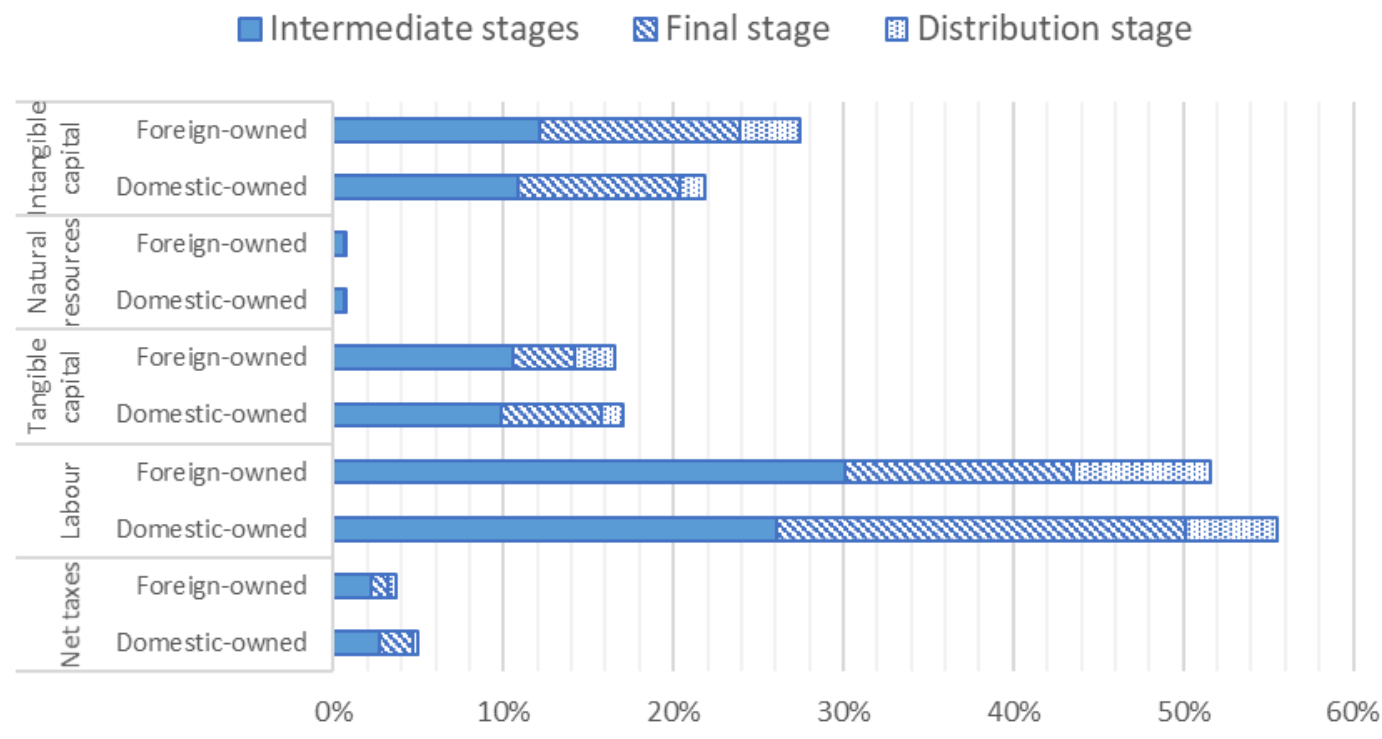

Source: Authors' calculations, see Annex A for data sources and methodology.

While on average across industries and countries, domestic-owned firms have $22 \%$ of their value added coming from returns to intangible capital, the share is $28 \%$ for foreign-owned firms. The difference comes from lower labour income and lower net taxes in the case of foreign-owned firms. There are also slightly lower returns to tangible capital for foreignowned firms but the difference is less than 1 percentage point. As labour costs are similar for domestic-owned and foreign-owned firms (since they operate in the same labour 
market), the difference can only come from variations in the labour mix (i.e. the type of workers employed) and the intangible capital intensity. Foreign affiliates of MNEs create relatively more value through intangible assets than through human capital as compared to domestic firms. Labour compensation remains nonetheless the main component of their value added with a share of $51 \%$.

The result for net taxes (i.e. taxes minus subsidies on products) is also interesting as it confirms that on average affiliates of MNEs have a lower share of their value added going to taxes. But it should be noted that only taxes on products (such as sales taxes or turnover taxes) are considered in this category and not corporate income taxes. ${ }^{1}$

Moreover, Figure 2.1 highlights differences in the production stage where income is generated. When looking at all factors of production, foreign affiliates have more income coming from the distribution stage and from intermediate production stages. It can be explained by a difference in the industries and stages of production where foreign affiliates operate. MNEs will tend to have a limited number of places where final production takes place (to exploit scale economies) but multiple foreign affiliates in their distribution network or network of suppliers. The value added is thus less concentrated in the final production stage. However, Figure 2.1 indicates that for intangible capital, a higher share of income corresponds to final production ( $43 \%$ of returns to intangible capital as opposed to $25 \%$ of labour compensation for example). This result suggests that foreign affiliates are even more intensive in intangible capital when producing final products.

\section{Figure 2.2. Breakdown of world returns to intangible capital in GVCs, 2016}

Share of returns to intangible capital and comparison with the share of gross value added (GVA in brackets)

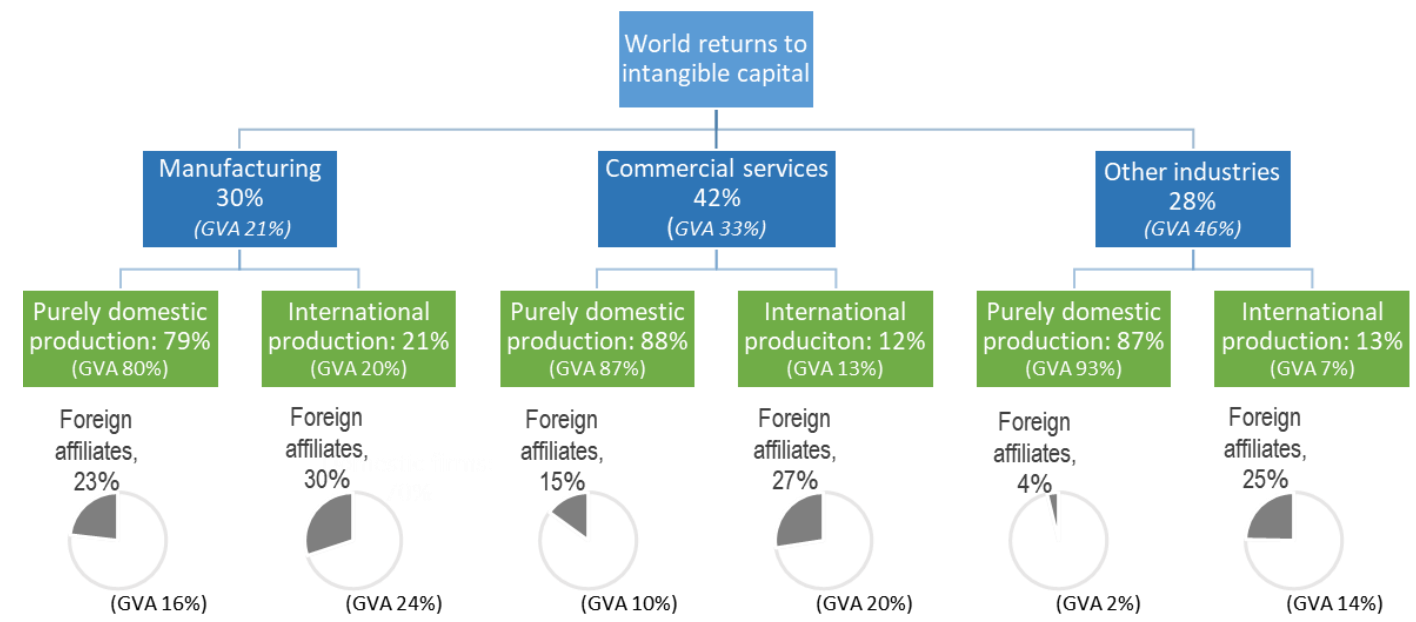

Note: The chart can be read as follows. Manufacturing firms account for $30 \%$ of world returns to intangible capital, as compared to $21 \%$ of gross value added (GVA). Returns to intangible capital in the manufacturing sector are then split between purely domestic production $(79 \%)$ and foreign production in GVCs $(21 \%)$. The respective shares for gross value added are $80 \%$ and $20 \%$. For the purely domestic production in the manufacturing sector, $23 \%$ of returns to intangible capital come from foreign-owned firms (as compared to $16 \%$ of gross value added). The distinction between purely domestic production and international production is based on the Leontief inverse used to calculate returns along the value chain (see Annex B).

Source: Authors' calculations, see Annex A for data sources and methodology.

Figure 2.2 provides a breakdown of world returns to intangible capital, as well as a comparison with gross value added (i.e. returns to intangible capital compared with returns 
to all factors of production). The Figure first confirms that foreign affiliates always have higher returns to intangible capital. The pie charts at the bottom of the Figure reveal a higher share of foreign affiliates in returns to intangible capital as compared to gross value added (GVA). For example, in the manufacturing sector and for value added derived from purely domestic production, $23 \%$ of returns to intangible capital originate in foreign affiliates while foreign-owned firms account for only $16 \%$ of gross value added.

The second takeaway from Figure 2.2 is that foreign affiliates generate returns to intangible capital both in domestic and international production networks, with their share of returns being higher in GVCs. The distinction between 'purely domestic production' and 'international production' is based on the input-output analysis and whether value added in final products was generated only through domestic industries or crossed some international border. The purely domestic production includes the contribution of foreign affiliates established in the domestic economy, providing inputs or performing the final assembly of products consumed in the domestic economy. Foreign affiliates found in the international production network are foreign affiliates established in other countries that participated in the production process of inputs or final products consumed in the domestic economy.

The share of returns to intangible capital going to foreign affiliates is the highest for international production, both in the manufacturing sector $(30 \%)$ and in commercial services $(27 \%)$. For other industries (that are mostly personal, social and public services), there is also a high share (25\%) explained by the foreign inputs imported by these sectors. Otherwise, foreign affiliates play a very minor role in domestic production for these activities ( $2 \%$ of GVA and $4 \%$ of returns to intangible capital). However, for manufacturing and commercial services, a high share of returns to intangible capital is also found in purely domestic production ( $23 \%$ and $15 \%$ respectively). Not only do foreign affiliates have a significant contribution to domestic production but they also add value to the domestic economy by deploying their intangible assets, some of them coming from their parent company.

Finally, Figure 2.2 highlights the important role of commercial services (construction, distribution, transport, hotels and restaurants, audio-visual, telecommunications, IT and information, financial activities and other business services) in the generation of returns to intangible capital. While these services account for one third of GVA, their share in returns to intangible capital is $42 \%$. They include some of the activities the most intensive in the use of intangible assets, as illustrated in the next Section.

\subsection{The contribution of foreign affiliates to returns to intangible capital varies across GVCs}

There is some heterogeneity when looking at returns to intangible capital across GVCs for specific industries. As illustrated in Figure 2.3, world returns to intangible capital are concentrated in a set of manufacturing and commercial services GVCs. In the manufacturing sector, three GVCs stand out: chemicals, food products and ICT \& electronics. Chemicals include pharmaceuticals and is not only the GVC with the highest returns to intangible capital in absolute terms but also the one where the contribution of foreign affiliates is the highest (with one third of returns to intangible capital coming from foreign-owned firms). Food products and ICT \& electronics are GVCs with high returns to intangible capital but the share of foreign-owned firms remains lower than in motor vehicles or other manufacturing (which includes furniture and toys). 


\section{Figure 2.3. World returns to intangible capital by GVC final product, 2016}

Manufacturing and commercial services, billion USD - Contribution of domestic-owned and foreignowned firms

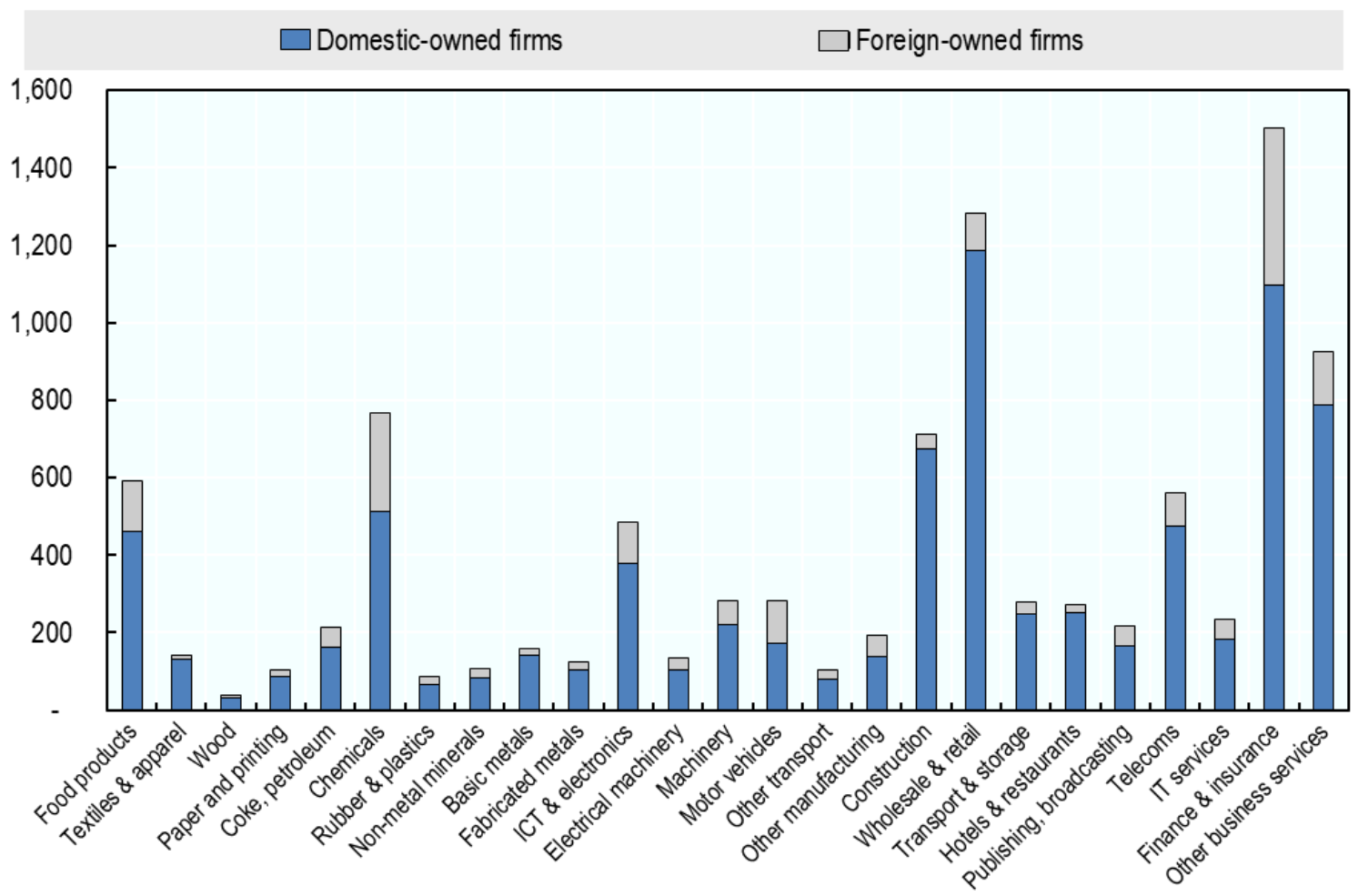

Source: Authors' calculations, see Annex A for data sources and methodology.

While pharmaceuticals and ICT \& electronics are industries where patents and intellectual property related to technology explain high returns to intangible capital, the fact that food products are among the three GVCs generating the highest returns highlights the importance of brands as intangible assets. The food sector is relatively less intensive in technology but investment in marketing and digital technologies on the distribution side can explain these high revenues generated by intangible capital. As our analysis is based on GVCs (i.e. includes the intermediate production stages and the distribution stage), it can capture this specificity of food GVCs.

In the commercial services sector, four GVCs account for the bulk of returns to intangible capital: finance \& insurance, wholesale \& retail, other business services and (to a lesser extent) telecoms. Finance \& insurance is not surprisingly the GVC with the highest returns to intangible capital in absolute terms. Not only it is one of the largest sectors of any economy but also it creates value all along its value chain through intangible assets, through financial research and innovation, as well as information and data on markets, companies and consumers. Finance $\&$ insurance is also the services GVC with the highest share of returns to intangible capital going to foreign-owned firms. Due to financial regulations, the provision of financial services (including insurance services) generally requires companies to be established in the economy of their consumers (Rouzet et al., 2014[29]). As crossborder provision is restrained, it is expected to find a more prominent role for foreign affiliates in this industry. Moreover, the financial sector is more internationalised than other services industries, as a consequence of the intangible nature of financial transactions 
(taking place in various financial markets) and policies initiated in the 1980s that have liberalised financial flows (Engwall and Hadjikhani, 2014[30]).

Wholesale \& retail trade is also a GVC generating more than USD 1 trillion of returns to intangible capital. It should be noted that in Figure 2.3 the returns of the distribution sector are included twice (and thus double counted): first within each GVC (such as within food products for the part of the GVC corresponding to the distribution stage) and then in the wholesale \& retail trade bar. This way we can show both the aggregate returns to intangible capital for all GVCs and their contribution to specific GVCs. As compared to finance \& insurance, the distribution sector relies less on foreign affiliates. Only $7 \%$ of the returns to intangible capital come from foreign-owned firms. Other business services (which include professional services, technical testing, consulting and management services) and telecoms have lower returns to intangible capital in absolute terms but are GVCs where foreign affiliates account for a larger share of intangible income (15\%).

\section{Figure 2.4. Breakdown of returns to intangible capital by GVC final product, 2016}

Share (\%) of domestic-owned and foreign-owned firms in purely domestic and international production

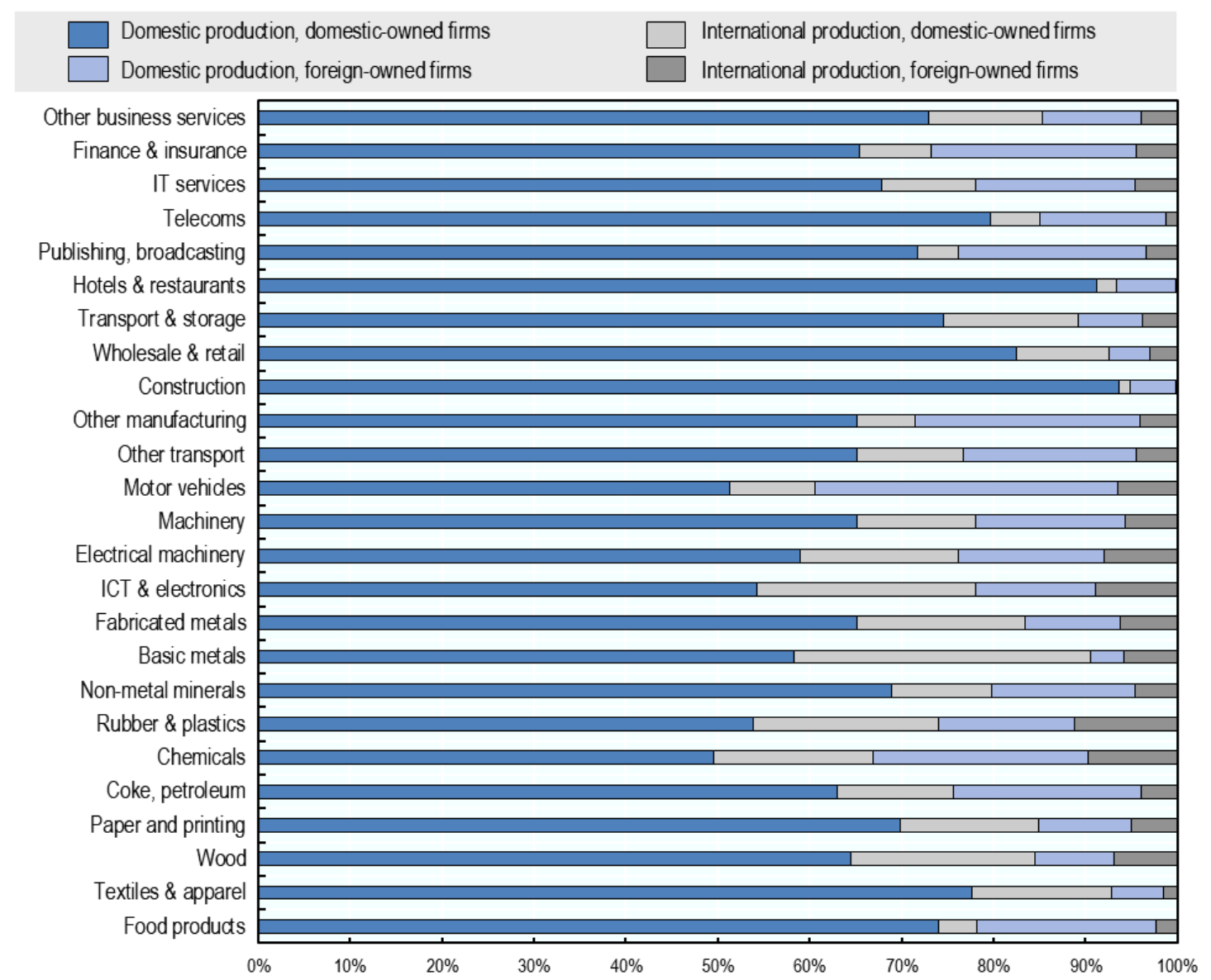

Source: Authors' calculations, see Annex A for data sources and methodology.

Figure 2.4 has information similar to Figure 2.3 but shows the returns to intangible capital of domestic-owned and foreign-owned firms in each GVC in relative terms. In addition, it indicates whether these returns come from the domestic or international production network. In relative terms, motor vehicles is the GVC where foreign affiliates account for 
the largest share of returns to intangible capital. It first reflects the fact that the automotive industry is often subject to policies that encourage domestic production or discourage imports (Sturgeon, Van Biesebroeck and Gereffi, 2008 ${ }_{[31]}$ ). Trade barriers and the pressure of governments to produce locally push foreign firms to enter the domestic market through FDI rather than trade. Figure 2.4 confirms this trend with a very high share of domestic production in the contribution of foreign-owned firms, implying that it is through affiliates established in the domestic economy that foreign firms generate income in the GVC.

But more related to intangible capital, the high share of foreign-owned firms in intangible returns in the automotive industry can also be analysed in relation to the recent trend of suppliers of parts and components playing a more prominent role in the GVC, as well as the entry of technology firms in the sector (Wong, 2019 [32] $)$. As more and more electronic components are incorporated in motor vehicles and cars become intelligent and selfdriving, returns to intangible capital are increasing. New players in the industry and the emergence of mega suppliers is also leading to more international value chains and more foreign affiliates as opposed to the traditional model of small domestic suppliers depending entirely on the domestic-owned or foreign-owned lead firm in the domestic economy.

A high level of returns to intangible capital coming from foreign-owned firms is found in most GVCs for raw materials. While the results for chemicals cannot be fully interpreted this way because pharmaceutical products are included, the rubber \& plastics and coke $\&$ petroleum industries illustrate this stylised fact. Rubber \& plastics is even the GVC with the highest share of foreign affiliates in returns to intangible capital from international production.

Lastly, among commercial services, publishing and broadcasting is after financial services the GVC with the highest returns coming from foreign-owned firms. The media industry is also well internationalised and has income derived from intellectual property products often produced abroad. Figure 2.4 highlights that foreign affiliates established in the domestic economy generate most of the returns to intangible capital, which can also come from policies that restrict cross-border trade and encourage the provision of services through establishment (Nordås et al., 2014 $\left.4_{[33]}\right)$.

\subsection{The share of high income countries in returns to intangible capital of foreign affiliates continues to increase}

Between 2005 and 2015, the share of high-income economies ${ }^{2}$ in world gross value added has decreased because their growth rates were on average lower than in middle-income economies. We observe the same for the share of returns to intangible capital (Figure 2.5). Middle-income economies have accumulated intangible capital at a higher pace than highincome economies. For the upper-middle income group (that includes Brazil, People's Republic of China (hereafter 'China'), Indonesia, the Russian Federation (hereafter 'Russia'), South Africa and other emerging economies), the share of returns to intangible capital has increased from $18 \%$ to $26 \%$ between 2005 and 2015 .

However, when looking at the breakdown between domestic-owned firms and foreignowned firms, we see that high-income economies concentrate most of the intangible capital income related to activities of foreign affiliates and that their share has increased between 2005 and 2015. The share of upper-middle income countries has also slightly increased, indicating that they are catching up and also developing their MNE activities. But their share remains small ( $3 \%$ in 2015) and is only one third of the share observed in high-income economies. Their accumulation of intangible capital remains mostly within domesticowned companies at this stage. The share of lower-middle-income economies in returns to intangible capital is below 1\% and together with the 'rest of the world' (not shown in 
Figure 2.5 and including the low-income group), these countries are the ones where returns to intangible capital from foreign-owned firms are becoming smaller between 2005 and 2015 .

Figure 2.5. Share of world gross value added and world returns to intangible capital, by country group

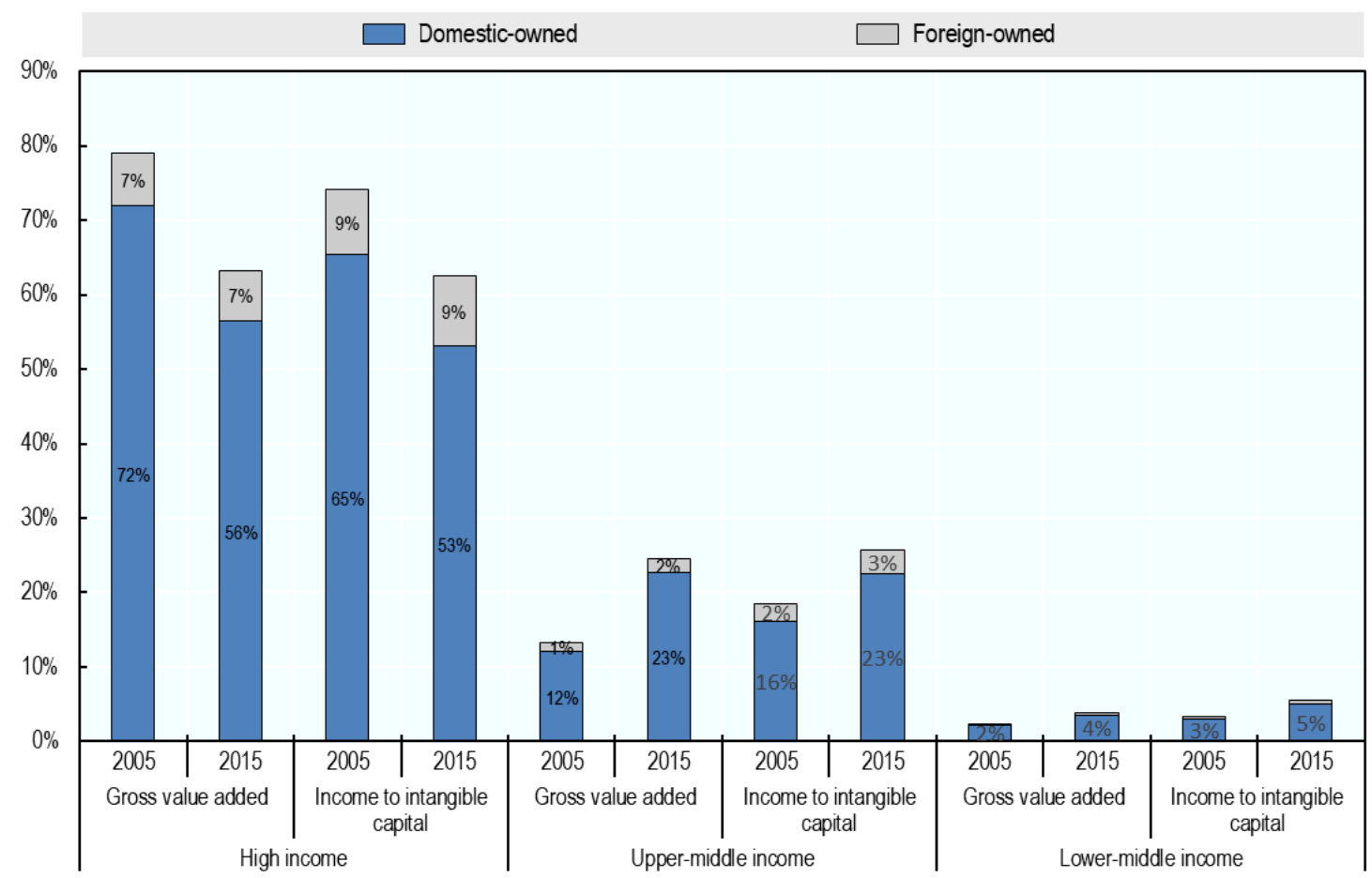

Note: The shares of high income, upper-middle income and lower-middle income economies do not sum to $100 \%$ because there is a 'rest of the world' with economies from the low-income group and economies from other groups not included in the dataset. The classification of economies comes from the World Bank: https://datahelpdesk.worldbank.org/knowledgebase/articles/906519-world-bank-country-and-lending-groups Source: Authors' calculations, see Annex A for data sources and methodology.

\section{How MNEs build competitiveness through intangible assets: case studies}

To better understand the way returns to intangible capital are generated, this Section introduces 5 case studies focusing on specific MNEs. The case studies are based on public information (such as the annual reports of firms) and data from the Factset database. They illustrate the role of intangible capital in the business model of MNEs and give a more concrete view of what their intangible assets are. They simultaneously demonstrate that patterns of knowledge creation and business strategies based on intangible assets differ across sectors. This heterogeneity reflects characteristics of each sector's technological environment, such as the difficulty of innovating as well as the degree of appropriability and cumulativeness of knowledge (Malerba and Orsenigo, 1997[34]; Van Assche, 2020 [2]; Malerba, $\left.2005_{[35]}\right)$. Five companies operating in different sectors are covered:

- Adidas is a provider of sports shoes, clothing and accessories. With a strategy centred on the outsourcing of production and strong design and distribution capabilities, Adidas is an example of a lead firm controlling production in a buyer- 
driven GVC. It increasingly relies on direct digital sales to increase value capture at the distribution stage.

- AstraZeneca is a large pharmaceutical firm that heavily relies on $R \& D$ in a producer-driven value chain with high barriers to entry. In an industry facing decreasing returns on its $\mathrm{R} \& \mathrm{D}$ investments, the company increasingly engage in collaboration agreements and mergers \& acquisitions (M\&A) deals to remain competitive.

- Rocket Internet is an internet company described as a start-up studio. It gained popularity in the 2010s by replicating innovative digital business models that have proven successful on other markets. It builds on its internal capabilities and experience in entrepreneurship to develop various models of internet retail businesses.

- Starbucks was a coffee bean retailer that turned into the largest coffeehouse chain in the world through a strategy focused on improving the experience of its customers. To ensure the quality and homogeneity of its products, it relies on internal processes and has developed a high degree of control over its value chain.

- Tata Consultancy Services is a consultancy company in the IT sector. It operates through a Global Delivery Model that coordinates the tasks of geographically dispersed teams. This model combines the benefits of geographical proximity to customers with location-specific comparative advantages.

\subsection{Adidas}

Adidas is an MNE specialised in sports shoes, clothing and accessories. Headquartered in Herzogenaurach in Germany, it employed nearly 60000 people worldwide and generated global sales amounting to more than EUR 23.6 billion in 2019. It operates in a sector that has seen lead firms increasingly centre their strategies on brand value and distribution (Lechner et al., 2020[36]). Having outsourced most of its production, Adidas is an example of a lead firm controlling production in a buyer-driven GVC.

A strong capacity to innovate contributed to the rise of Adidas as a large provider of sporting goods in the 1950s and 1960s. ${ }^{3}$ Within five years of having established the company in 1949, Adolf Dassler had filed more than 60 patents at the German patent office. By 1955, Adidas was exporting to 55 countries. The first foreign subsidiaries were established in Canada (1958), France (1959) and South Africa (1972) (Holtbrügge and Schuster, 2017 $[37]$. The 1970s saw production shifting towards Asia. In the wake of severe financial difficulties, this trend accelerated in the 1980s and 1990s. Today Adidas focuses on design, marketing and distribution, with nearly $100 \%$ of production outsourced to manufacturing suppliers. ${ }^{4}$

\section{International linkages and strong partners help to meet demand for newness}

Regarding the design stage, as well as the production and distribution stage, intangible assets constitute the foundation of the company's strategy. Since newly launched products are generally associated with higher margins, the creativity of the Adidas' product developers and designers is a key determinant of its growth prospects. Its R\&D activities are concentrated at the global headquarters in Germany and at the United States headquarters in Portland, Oregon. The Asia-Pacific headquarters in Shanghai contributes to the smooth transition from the development stage to the production stage. In addition, the company has identified six key cities - New York, Los Angeles, Paris, London, 
Shanghai and Tokyo - as influential hubs where it observes new trends and seeks to source relevant knowledge inputs. ${ }^{5}$

With consumers displaying a growing demand for newness, sportswear companies have been shortening product cycles. Products launched in 2019 accounted for more than three quarters of all sales of Adidas-branded products in that year. Conversely, products introduced more than two years ago accounted for only $3 \%$ of sales (Adidas, $2020_{[38]}$ ). According to information included in the WIPO global design database, during the years 2015-2019 Adidas registered on average more than 290 new industrial designs per year. ${ }^{6}$ In its efforts to innovate, the company draws on its existing stock of knowledge assets. ${ }^{7}$ For example, a set of shoe models launched in recent years combines new materials with the design of products introduced in the 1970s and 1980s.

Adidas collaborates with several universities, such as the University of Calgary in Canada and the University of Erlangen-Nürnberg in Germany. Similarly, it maintains close links to companies such as BASF. As one of the world's largest R\&D spenders in the chemicals industry (Hernández et al., 2018 [39]), BASF acts as a major supplier of advanced materials, e.g. special foam used for Adidas' "Boost" running shoes and sneakers. Such strategic partnerships guarantee access to novel components, which enable Adidas to exploit earlymover advantages. ${ }^{8}$ Further examples of strategic partnerships include Adidas' collaboration with Carbon, a US company specialised in 3D printing, and Parley for the Oceans, an organisation focused on polyester recycling.

With its headquarters located in a town of less than 25000 inhabitants, openness to external knowledge inputs and international linkages are of pivotal importance to Adidas' ability to innovate. Horst Dassler, the son of the company's founder and CEO of Adidas between 1985 and 1987, played a pivotal role in developing the company's marketing strategy and international expansion whilst being primarily based in France rather than Germany. In 1989, against the backdrop of rapid losses of market share to its main competitor, Nike, and poor business results, Adidas contacted two former Nike managers in the search for new ideas. Peter Moore and Rob Strasser joined Adidas and combined the marketing experience they had gained at Nike with Adidas' history. The two branding experts introduced a new product line and defined an approach inspired by the founding years of the company and its traditional focus on athletic performance.

\section{The central role of the company's brand value}

Its proximity to athletes constitutes a central pillar of Adidas' strategy. On the one hand, the feedback and data received from individuals (e.g. Lionel Messi) and teams such as Real Madrid can be used as valuable inputs for product improvements. At the same time, collaborations with well-known athletes strengthen the company's brand value. Historically, nearly half the marketing budget has been allocated to what Adidas describes as "partnership assets", i.e. collaborations with influential individuals that also involve musicians (e.g. Beyoncé, Kanye West) as well as social media influencers.

The Adidas subsidiary in Amsterdam plays a central role in managing such sponsorships. It also coordinates the company's trademark, patent and design filings as well as activities related to brand protection. Yet, the brand value as well as the company's intangible assets more generally are exploited in all markets. The case of Adidas therefore illustrates that the creation and management of intangible assets is often concentrated in a small set of locations, but their scalability enables firms to generate returns to these assets across many products and countries.

With the majority of Adidas' employees focusing on activities related to product design, supply chain management, marketing and distribution, virtually 100 percent of production 
is outsourced. Factories in Viet Nam, the primary sourcing country for shoes, produced roughly 190 million pairs of Adidas shoes in 2019 (43\% of Adidas' total footwear volume). Further important sourcing countries include Indonesia (28\% of footwear production), Cambodia ( $23 \%$ of apparel) and China ( $37 \%$ of hardware, e.g. bags and balls). ${ }^{9}$ In line with the role of lead firms in buyer-driven GVCs, the production activities of Adidas' manufacturing suppliers rely on Adidas' intangible assets, e.g. the design of a football shoe. Adidas provides its contractors with instructions and training, but the ownership of the intangible capital rests with Adidas.

In 2019, the company collaborated with 138 manufacturing suppliers that operated 336 plants. Despite not being easily measurable, the capacity to coordinate this complex supply chain constitutes an intangible asset in itself. For example, it requires legal and managerial expertise to design contractual arrangements that limit the risk of IPR infringements and ensure suppliers meet quality standards. Similarly, potential disruptions to the flow of components from suppliers such as BASF (headquartered in Germany) or Dongsung Chemical (Korea) to manufacturing contractors must be minimised. The efforts to optimize this network can be regarded as an investment in an intangible asset. Adidas categorises links to particularly important contract manufacturers as "key strategic partner relationships". In 2019, this category encompassed 45 (out of 138) manufacturing suppliers that accounted for $90 \%$ of the total production volume. Reflecting a supply chain strategy shaped by a long-term perspective, the 45 companies considered as "strategic key partners" had on average been acting as a strategic supplier for Adidas for 17 years (Adidas, 2020 [38]).

While nearly three quarters of the contractors that manufacture Adidas products were located in Asia in 2019, the geography of sales is less concentrated. According to estimates of the financial data provider FactSet, in 2019 mainland China was estimated to account for $23.5 \%$ of total sales, followed by the United States (21.5\%). Further key markets include Germany (5.5\%), Russia (3.1\%), India (2.1\%), and Brazil (2\%).

\section{Efforts to increase value capture at the distribution stage}

The company uses four main channels to distribute its products. First, it owns more than 2500 retail stores. Second, there are more than 2500 mono-branded Adidas franchise stores. Third, the company also sells its products to large retailers that have more than 150000 stores. Fourth, consumers can make purchases on the e-commerce platform of Adidas. Particularly since the company's strategic reorientation initiated by the then CEO Robert-Louis Dreyfus in the 1990s, Adidas has been seeking to expand its control of the distribution stage. In order to strengthen the company's ability to shape the position of the brand and the company's reputation, Dreyfus limited the role of licensing partnerships and shifted the focus towards joint ventures and fully owned retail subsidiaries.

As part of efforts to increase value capture at the distribution stage, Adidas established a set of distribution management units dedicated to specific macro regions in the late 1990s. For example, a team based in Panama directs the distribution activities in Latin America. When Reebok was added as a brand to the Adidas' portfolio in 2006, Adidas' strategy of buying out distributors and joint venture partners to achieve greater power at the distribution stage was similarly applied to Reebok. ${ }^{10}$ Thus, the company bought the exclusive distribution rights for Reebok in China and Russia in 2006 and also gained full control of the distribution rights in Argentina and Brazil in 2016.

Adidas refers to retail facilities that it directly controls, especially own-retail and franchise stores as well as its e-commerce platform, as "controlled space". The company intends to generate $60 \%$ of its total revenue through such channels in 2020 and investments in corresponding facilities accounted for $47 \%$ of total capital expenditure in $2019 .{ }^{11}$ 
In recent years, the share of online sales has been growing rapidly. In 2019, revenue generated via the company's own e-commerce platform increased by $34 \%$ - faster than all other distribution channels (Adidas, 2020 $\left.0_{[38]}\right) .{ }^{12}$ Direct digital sales are associated with higher margins than traditional retail channels. They enable the company to reduce expenses related to third parties, such as retail partners, and provide opportunities to collect valuable data on consumer preferences. As Adidas invests in its e-commerce capacities, the role of its "brick-and-mortar" stores is changing. Their total number is likely to decline in the next few years, but stores in key cities are increasingly regarded as locations that define the identity of the brand and complement the company's digital presence. Large flagship stores, such as the ones on Champs Élysées in Paris, are considered as an important element of the company's marketing and distribution strategy.

Adidas' distribution strategy aims at exploiting synergies across different distribution channels, e.g. by offering customers the opportunity to purchase items online and collect them in a street-side store. The design of the new flagship store on London's Oxford Street incorporates more than 100 digital elements. A mobile application offers the customer options to book slots for activities offered by the stores, such as running tests. Inside the shop, RFID technology is employed to enable the mirrors in changing rooms to recognise the products chosen by the customer in order to display additional information.

\subsection{AstraZeneca}

AstraZeneca is a large pharmaceutical company with headquarters in Cambridge in the United Kingdom that was created through the merger of the Swedish company Astra AB and the British company Zeneca in 1999. Astra AB had traditionally been involved in the distribution of penicillin in the Swedish market since 1948. It was also specialised in gastroesophageal treatment with its blockbuster ${ }^{13}$ drug Losec. Zeneca was founded in 1993 by the demerger of the pharmaceutical and agrochemical activities of a large British chemical company (Imperial Chemical Industries). In the middle of the 1990s, the company started to focus on new approaches for the treatment of cancer and acquired one of the leading providers of cancer health care in the United States.

The merger of Astra and Zeneca led to the creation of a large pharmaceutical company with a strong science-based culture specialised in five main areas of research: cardiovascular, gastrointestinal and respiratory therapy, oncology and anaesthesia. At the time of the merger, sales were still led by the leading product Losec for which revenues were more than USD 6 billion (representing 55\% of total revenues in 2000). With 150 products in the 'pipeline' (see below), the company quickly aimed at producing new products but also at expanding in new markets.

\section{The pharmaceutical industry is organised around the production of intangible capital}

The pharmaceutical's industry turnover has reached USD 1.25 trillion in 2019 (IQVIA, $\left.2020_{[40]}\right)$. It has increased fourfold since 2001 as a result of the ageing of populations in developed countries and a better access to medicines in new emerging markets. Global demand nevertheless remains highly concentrated in the United States, accounting for $41 \%$ of global consumption in 2019 (IQVIA, 2020[40] ).

The pharmaceutical industry is one of the most intensive in intangible capital. The OECD BERD database shows that R\&D expenditure make up 30\% of GDP in the pharmaceutical industry as compared to $1.6 \%$ on average in other manufacturing sectors. ${ }^{14}$ Patents and their enforcement play a specific role in the industry and define the life cycle of drugs. In addition, links between governments and the pharmaceutical industry create a tension 
between regulation and innovation (Lakdawalla, 2018 ${ }_{[41]}$ ). Governments provide the right to access the market through their regulatory bodies ${ }^{15}$ and create the legal environment in which pharmaceutical firms operate. They are also often the main customer of the industry through their social insurance systems and can participate actively in the innovation process through subsidies or publicly funded universities (OECD, 2018 $\left.8_{[42]}\right)$.

Two types of firms - i.e. branded firms and generic firms - develop a wide array of products ranging from healthcare products sold over the counter (OTC) to prescribed drugs. Between 2000 and 2007 , branded firms spent $17 \%$ of their turnover on R\&D (1.5\% on fundamental research and $15.5 \%$ in new trials), $23 \%$ on marketing and market research, and only $21 \%$ on production; as a comparison, generic firms spend $51 \%$ of their turnover on production (EC, 2013 [43] $)$. The cost of development of a medicine is between USD 1 billion and USD 2.5 billion (Lakdawalla, 2018 ${ }_{[41]}$ ) and its development cycle from its discovery to its release on the market is around eight to ten years.

The two types of firms operate in two complementary markets: branded firms bear the risks of innovation and when the enforcement period of a branded product ends, generic firms subsequently enter the market by copying the formula and providing the medicine at a reduced price.

The different phases of a product life cycle are: the pipeline when the firm develops the new drug or product through several R\&D steps (discovery, pre-clinical testing and clinical trials of potential new treatments in humans); the period of exclusivity during which the firm produces and markets the product while trying to extend the period of exclusivity; and lastly, the period of competition with generic firms that aim at producing a bioequivalent product. The time interval is of around 20 years from the discovery to the end of exclusivity of a product. Since the development stage is of around 8 to 10 years, 10 years at best are remaining for oligopolistic competition. After the end of exclusivity, generic firms spend on average seven months to enter the market but branded firms try to extent the period of exclusivity by submitting patent clusters or through reversal payments (i.e. payments to generic firms to stop selling the product). 
Figure 3.1. AstraZeneca's blockbuster products from 2000 to 2019

Sales in USD million

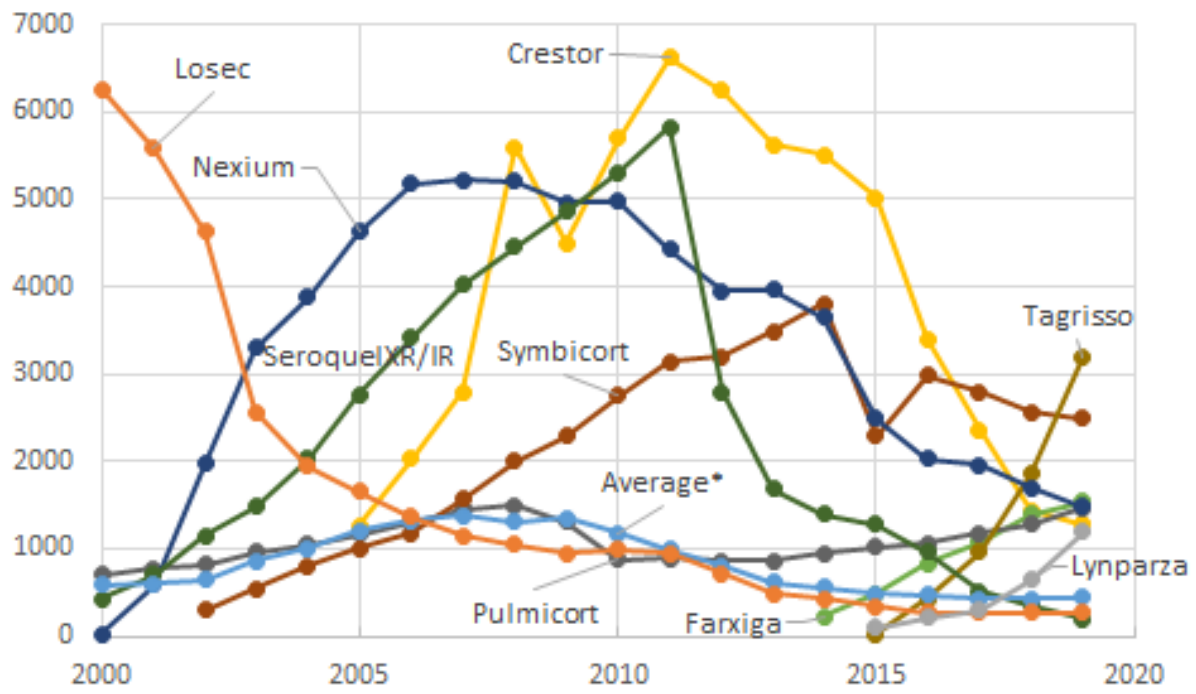

Note: Average* is the average between Arimidex, Seloken, Casodex, Atacand and Zoladex that have a similar trend.

Source: AstraZeneca's annual reports.

Figure 3.1 shows AstraZeneca's products life cycles with a very fast growth of blockbuster drugs just after their approval - like Nexium or Crestor - but also with a very fast decrease after the period of exclusivity. The company must proactively innovate in new drugs in order to prevent blank time zones when no new drug is released and when the period of exclusivity of former blockbusters ends. Sales at a given point in time are typically the results of R\&D that happened a dozen years before.

As can be seen on Figure 3.1, the situation of AstraZeneca was difficult after 2012 with the end of exclusivity of leading products such as Atacan, Nexium, Seroquel IR and Crestor. In 2018, the company had lost one third of its revenues as compared to 2011. But at the same time AstraZeneca was developing new cancer drugs that would become more lucrative by the end of the 2010 s.

\section{Declining returns to $R \& D$ in the pharmaceutical industry and the response of AstraZeneca}

Over the last 15 years, the productivity of R\&D (i.e. the costs associated to the development of new medicines in the pipeline related to the expected sales after launch) has been continuously decreasing (Berndt et al., 2015 $5_{[44]}$; Deloitte Centre for Health Solutions, $\left.2019_{[45]}\right)$. The costs of R\&D have increased while policymakers and health systems put more pressure on reducing spending and lowering the price of medicines. Moreover, only $14 \%$ of drugs in the pipeline receive market approval after a median time of 8 years of clinical development (OECD, 2018 ${ }_{[42]}$; Wong, Siah and Lo, 2018 $\left.8_{[46]}\right)$. This low probability of success, the all or nothing nature of the development process and competition makes the process risky.

Bloom et al. $\left(2020_{[47]}\right)$ compare the decrease in mortality against the research efforts. They show that the years of life saved per 100000 people by the publication of clinical trials have decreased from 8 years to one year from 1985 to 2006 . This decrease has been labelled 
by the industry's professionals as the Eroom's law (which goes in the opposite direction of the Moore's law regarding innovation in high-tech industries). According to the Eroom's law, expenditures on R\&D must double every nine years to achieve the same clinical outcome (Scannell et al., 2012 $2_{[48]}$ ).

To increase their returns, pharmaceutical companies have focused on developing niche drugs and more personalised treatments. For instance, in the United States in 2019, 81\% of novel drug approvals were targeted drugs (i.e. personalised medicines) (Wang and Sun, $\left.2020_{[49]}\right)$. Pharmaceutical companies also shift their activities towards services and communicate more and more with patients. According to Flores, Glusman, Brogaard, Price and Hood $\left(2013_{[50]}\right)$, there is a new P4 medicine that stands for predictive, preventive, personalised and participatory.

New digital technologies also improve the personalisation of treatment. Pharmaceutical companies now collaborate with IT firms in order to introduce artificial intelligence and data analytics into their processes. Investment in AI in the pharmaceutical industry has increased by 9 times between 2014 and 2020 (DPI, 2021 $1_{[51]}$ ).

We clearly see these trends in AstraZeneca's strategy with a focus on unmet medical needs following its decreasing sales in the 2010s. The company has reinforced its capabilities in more specific treatments involving biologics, immunotherapies and antibody engineering. It has developed 6 new medicines since 2013 - especially for the treatment of cancer. In 2019 , newly developed medicines represented $42 \%$ of sales with revenues increased by $10 \%$ as compared to 2018 .

Another way through which pharmaceutical firms are addressing the decrease in R\&D productivity is by lowering the costs of R\&D (Schuhmacher, Gassmann and Hinder, $\left.2016_{[52]}\right)$. In branded firms, research is either done internally or through acquisitions of specialised laboratories with the final objective of developing medicines that will be protected by patents. Whereas the innovation process has historically been done vertically and within the boundaries of firms, pharmaceutical companies have started to outsource R\&D in the 1990s and this trend has accelerated after the 2008 financial crisis (McMeekin et al., 2020 $[53])$. Moreover, the industry relies more on collaboration, open science and open innovation (Chesbrough and Press, 2003 ${ }_{[54]}$; Gold, 2021 $1_{[55]}$ ). As the development of new drugs requires knowledge from a wide array of specialised fields (such as microbiology, biochemistry, genetic, molecular biology, etc.), pharmaceutical firms increasingly engage with start-ups, universities and specialised communities.

In the mid-2000s, AstraZeneca started to expand its R\&D activities through the acquisition of specialised laboratories. In 2007, it acquired MedImmune, a biotech company specialised in biologics and vaccines. It was the first time AstraZeneca was developing research in vaccines. It also acquired two other dedicated biological laboratories, KuDOS Pharmaceuticals in 2005 and Cambridge Technology in 2006. More recently, it also acquired Alexion (in 2020) to reinforce its presence in immunology and the development of treatments for rare diseases.

In addition, AstraZeneca developed many collaborations, such as with the Japanese firm Daiicho for new cancer treatments. As of 2019, AstraZeneca has more than 760 collaborations and a budget of USD 1.8 billion in collaborations with a focus on unmet medical needs. It is also through a collaboration with Oxford University that AstraZeneca developed its COVID-19 vaccine in 2020.

\section{AstraZeneca's network of foreign affiliates}

AstraZeneca operates in 26 sites in 16 countries (Figure 3.2). As of 2019, it has 70600 employees. Most affiliates of AstraZeneca are in Europe where the company is 
headquartered. Other affiliates are in the United States and in East and South East Asia, two regions accounting for a significant share of its global sales. China and other emerging markets represented $35 \%$ of sales in 2019 with a growth of $18 \%$. If most affiliates are classified in the core business activity of AstraZeneca (i.e. the pharmaceutical industry), Figure 3.2 highlights the role of R\&D centres in cities like Palo Alto or Seattle. In 2019, the firm strengthened its $R \& D$ activities in Asia with an investment in a new $R \& D$ centre in Shanghai.

\section{Figure 3.2. AstraZeneca's network of affiliates}

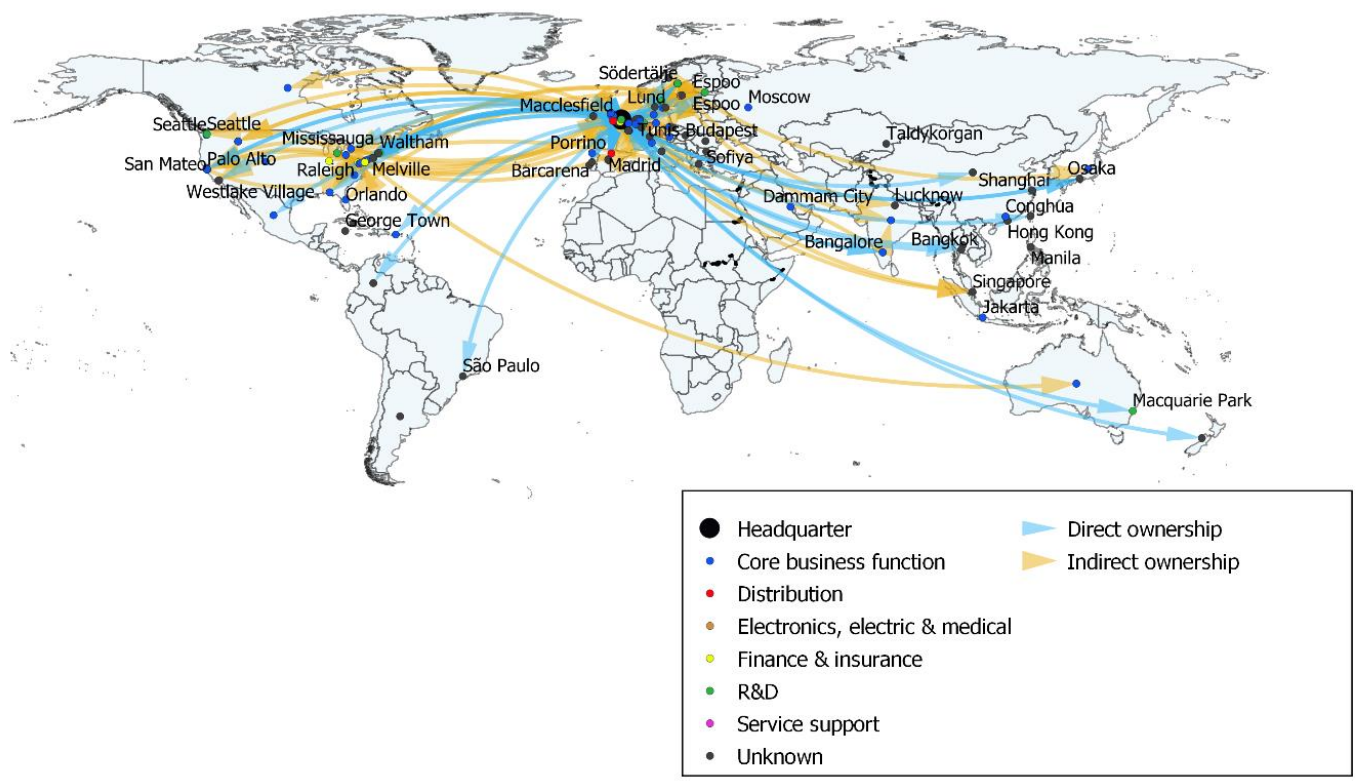

Source: FactSet.

In terms of manufacturing capabilities, the company still uses external sourcing complemented by internal capability. It has production sites in the United Kingdom, Sweden, China, the Netherlands, the United States, France and Australia. It has supply sites in Russia, Japan, Indonesia, Egypt, Germany, India, Mexico and Brazil. For the production of COVID-19 vaccines, the firm has engaged in partnerships with other firms from the pharmaceutical industry to rapidly ramp up production, such as Emergent BioSolutions in the United States, the Serum Institute of India, or SK Bioscience in Korea.

\subsection{Rocket Internet}

Rocket Internet is a German-based internet company that has gained popularity in the 2010s by reproducing the business model of digital start-ups in new markets. It mostly engages in e-commerce, marketplaces, financial technology and the travel sector. Rather than focusing on innovation and new ideas, the three Samwer brothers who have founded the company aim at efficiently recreating digital business models that have been proven successful. The company's strategy therefore exploits the scalability of intangible assets an aspect that has been emphasized with respect to internet-based business models (Haskel and Westlake, 2018[56] $)$.

Referred to as the start-up factory (Baumann et al., 2018 ${ }_{[57]}$ ), Rocket Internet has spearheaded famous platforms such as Lazada in Southeast Asia, Zalando in Europe and Jumia in Africa, which are now all listed on stock exchanges. More recently, it has 
developed platforms such as DeliveryHero, HelloFresh, Westwing and Wimdu with more than 20 starting business models in sectors such as fashion, home, food and grocery, and general merchandise. As of 2018, Rocket Internet provided employment for more than 42000 people. $^{16}$

\section{Development of internal capabilities that heavily rely on intangible capital}

Rocket Internet built its first platform Zalando in Germany. The Samwer brothers had the idea of creating this platform based on their own customer experience in the 1990s. E-bay, the leading e-commerce platform, was present in some European countries but not in Germany. The brothers started their own application based on this model and developed a marketplace for the German market.

Now Rocket Internet focuses on efficient production by improving its capabilities rather than focusing on innovation and exploring risky ideas (Baumann et al., 2018 $8_{[57]}$ ). Its innovation is at the operational level in the way it replicates business models, assembles and scales companies through a vertical management with decisions made at the headquarter level.

One of Rocket Internet's clear objective is to develop a network of complementary companies that it supports. In addition, to achieve this objective, it develops an operational expertise, leads management and invests strategically. Even though local entrepreneurs are hired, the overall strategy is chosen by the Berlin headquarters. While all the business to business and business to consumers activities are carried out by its affiliates, Rocket Internet has a central function and remains responsible for the launch of the businesses, for the recruitment of the necessary personnel and IT experts.

When failing, the decision to close a business is done at the headquarter level as well and based on the behaviour of consumers towards the developed product. If new businesses do not necessarily aim at profitability, they are evaluated through specific key performance indicators (KPIs) a few months after their creation.

At the headquarter level, the firm provides proprietary technology as well as functional expertise to its companies (Rocket Internet, 2019 $9_{[58]}$ ). While Rocket Internet does not follow the start-up culture, its management approach where business development is codified and systemised is close to lean management (Ries, $\left.2011_{[59]}\right) \cdot{ }^{17}$ When applied to digital businesses, lean management relies on design thinking, customer development, agile development, extremely fast cycles and scientific approaches.

After the decision of creating a new business is taken, Rocket Internet develops it from scratch in a very short time period. Key performance indicators (KPI) are given and closely monitored every week. The company can very quickly hire hundreds of people for customer service, supply chain and logistics. New businesses can start in small warehouses and occupy a surface of several thousand square meters a few month later. Lastly, a short time after the creation of a new business, up to USD 20 million are spent every month in Facebook and Google ads. ${ }^{18}$

While traditional businesses face 'liabilities of foreignness', digital companies face 'liabilities of outsidership' that appear when there is a lack of links, knowledge and legitimacy in new markets (Chen et al., 2018[60] $)$. The main purpose of digital firms investing in a new country are to become embedded in the country. They seek to become an integrated actor of this new market. Strategies differ from traditional businesses that expand through FDI. Digital companies try to establish new partnerships with counterparts abroad to extend the number of users in their network (Cahen and Borini, 2020 ${ }_{[61]}$ ). UNCTAD (2017 $\left.{ }_{[62]}\right)$ reports that internet platforms have ratios of foreign sales to foreign assets of 2.6 as compared to a ratio of one for non-internet companies. 
Rocket Internet overcomes liabilities of outsidership through a very efficient and fast market integration that provides its businesses with a first mover advantage. Part of the intangible capital of the firm is its sense of what KPIs should look like after a given time of operation.

\section{Rocket Internet and Haskel \& Westlake's four Ss}

Through its digital activities, Rocket Internet perfectly illustrates the four Ss of intangible capital described by Haskel and Westlake $\left(2018_{[56]}\right)$. First, since the company relies on the innovation of its incumbent firms, it benefits from the spillovers of their intangible capital.

Second, Rocket Internet is developing only internet-based business models that are scalable and with attractive levels of profitability (Rocket Internet, 2019 [58]). When Rocket Internet invests in a firm, it invests in the creation of a network whose value is based on its number of users (Katz and Shapiro, 1985 ${ }_{[63]}$ ). The network effect has given name to the Metcalfe's law, which states that the effect of a network is proportional to the square of its number of participants.

Third, Rocket Internet produces complementary applications on different sectors and geographic markets to produce synergies and increase its network so that "each individual company of the network complements each other in such a way that each additional part of the network promotes the strength of the network in many possible dimensions" (Rocket Internet, 2019 $\left.{ }_{[58]}\right)$. In 2019, the company claims 78 fully consolidated companies among which 48 are outside Germany (Rocket Internet, 2019[58]). For example, it has developed know-how in payment systems that facilitate the user experience of the applications it is investing in. Rocket Internet has invested in different markets and sectors like home appliances, delivery, fashion, that provide at the same time a diversification of its portfolio, but also a complementarity in terms of required knowledge and inputs to implement them.

Fourth, the firm invests in more than 200 companies, many of them not successful or not reaching a critical size for further development. Part of the investments in those firms fall into impairment and constitute sunk costs. One important aspect of Rocket Internet's incubation process is its necessity to keep as much liquidity as possible to invest in new businesses but also to face closing businesses (Baumann et al., 2018 [57]). In its 2019 annual report, Rocket Internet has EUR 1.6 billion cash and cash equivalent. In 2014, it has created an entity called Global Founder Capital worth USD 194 million for start-up funding and more recently in January 2021, it has created a USD 1 billion fund called Rocket Internet Capital Partners (RICP).

\section{Unmeasured intangible capital as a source of revenues}

The new businesses started by Rocket Internet do not generate high revenues or only several years after their creation. To generate revenues, Rocket Internet sells stakes of its affiliates that are valued according to the future revenues they will generate, which themselves are function of their network of customers. Networks of customers of Rocket Internet businesses constitute intangible capital that investors pay for, although one cannot directly identify their value in their balance sheets. 
Table 3.1. Rocket Internet's income statement

\begin{tabular}{l|r}
\hline In EUR million & 2019 \\
\hline Revenue & 67.3 \\
\hline Other operating income & 9.7 \\
\hline Result from deconsolidation of subsidiaries & 8.4 \\
\hline Cost of materials and cost of financial services & -14.4 \\
\hline Employee benefits expenses & -41.3 \\
\hline Other operating expenses & -51.9 \\
\hline Share of profit/loss of associates and joint ventures & 203.8 \\
\hline = EBITDA & $\mathbf{1 8 1 . 6}$ \\
\hline Impairment of non-current assets, depreciation and amortization & -11.7 \\
\hline Financial result & 118.7 \\
\hline Income taxes & -8.4 \\
\hline = Profit/loss for the period & $\mathbf{2 8 0 . 3}$ \\
\hline Other comprehensive income for the period, net of tax & 14.8 \\
\hline = (net income) Total comprehensive income/loss for the period, net of tax & $\mathbf{2 9 5}$ \\
\hline
\end{tabular}

Source: Rocket Internet annual report, 2020.

We can clearly see this in Rocket Internet's income statement (Table 3.1). Two third of the total income comes from "share of profit/loss of associates and joint ventures". Those operations mainly correspond to the sales of equity of unconsolidated affiliates. For instance in 2019, Rocket Internet sold HelloFresh, DeliveryHero and home24 shares.

As illustrated in Figure 3.3, ownership of Rocket Internet in its affiliates decreases as revenues of the new businesses increase. For example, the revenues generated by HelloFresh were EUR 70 million in 2014 with an ownership of 51.7\%. In 2018, the revenues increased to EUR 1278 million while the ownership decreased to $30.6 \%$. Lazada was sold to the Chinese company Alibaba in 2016 and Jumia was also sold in 2020.

\section{Figure 3.3. Rocket Internet's main businesses}

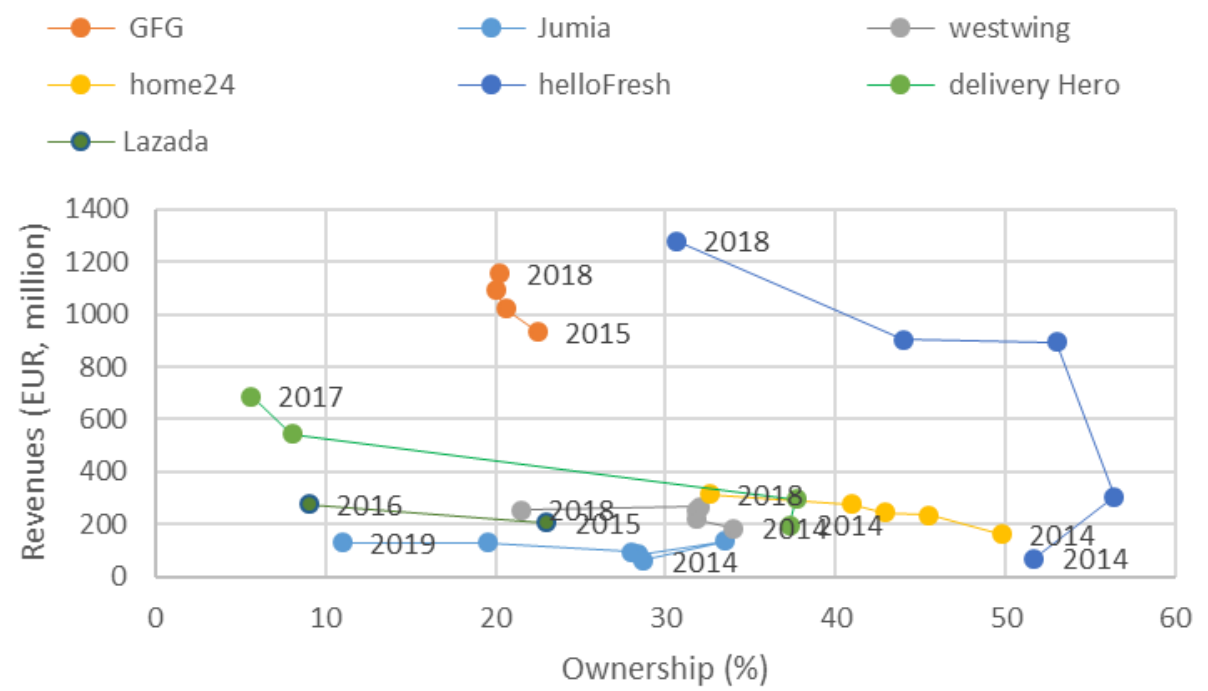

Source: Rocket Internet annual reports, 2014-2019. 
While most of its revenues come from the divestment of its start-ups that are intensive in intangible capital, Rocket Internet does not show an important share of intangible capital in its balance sheet. Intangible capital solely accounts for EUR 1.9 million - much less than one percent of its total long-term assets. While Rocket Internet undeniably builds is value on intangible capital, its main assets correspond to investments in associates and joint ventures which represent the valuations of the affiliates that Rocket Internet has invested in and that are now unconsolidated from the group (like HelloFresh for instance). The intangible capital it benefits from is the one accumulated in the successful companies it helped to build. For example, Rocket Internet owns 20\% of the Global Fashion Group of which goodwill and intangible capital account for around 60\% of its assets (GFG, 2019[64]). Rocket Internet is another illustration of the difficulty in measuring intangible capital and its contribution to economic activities.

\subsection{Starbucks}

The first Starbucks store opened in Seattle in 1971. Founded by Jerry Baldwin, Zev Siegl and Gordon Bowker, the company only sold coffee beans until 1984. This is the year Howard Schulz convinced the three owners to test the concept of a coffeehouse serving espresso-based drinks. Inspired by a trip to Milan where he discovered espresso bars, Schulz later started his own company and bought Starbucks. He quickly expanded the firm and made it a successful multinational chain of coffeehouses.

As of 2019, Starbucks had 346000 employees and served coffee and tea products in 31256 locations over 80 countries. ${ }^{19}$ The same year, the sales of the company were USD 26.5 billion with a profit of USD 4 billion. In 2020, Starbucks was impacted by COVID-19 and closed 500 stores in the United States and 200 in Canada. However, it was still expanding with 850 new stores planned to open. ${ }^{20}$ The company adapted by focusing on carryout and pickup orders and by opening new curbside pickup and drive-thru stores. ${ }^{21}$

While Starbucks is still roasting and selling coffee beans to its customers, packaged coffee and tea accounts for only $1 \%$ of the retail mix. ${ }^{22}$ The company still has revenues coming from sales of packaged coffee to groceries and specialty retail stores. But the core business of Starbucks consists in sales of beverages in coffeehouses. Unlike other multinational chains in the food and beverage industry, Starbucks is not fully relying on licensing or franchising. A bit more than half of Starbucks stores (15 834 in 2019) are companyoperated and they account for $81 \%$ of revenues. Licensed stores are more prevalent abroad (56\% of international stores) as compared to the domestic market (45\% of stores). Franchising is limited to a small number of markets outside the United States with selected partners.

\section{The Starbucks experience is the main intangible asset of the company}

What Starbucks sells is not coffee but what the company describes as the 'Starbucks experience'. It is not well defined but involves personal connections, an attention to all details (e.g. the perfect shot of espresso or free wifi access), a neighbourhood feel and some innovation to constantly surprise and delight customers (Michelli, 2007 ${ }_{[65]}$; Schultz, $\left.2011_{[66]}\right)$. This customer experience, and the know-how required to provide it, can be regarded as the main intangible asset of the company. As explained by Howard Schulz, "a well-built brand is the culmination of intangibles that do not directly flow to the revenue or profitability of a company, but contribute to its texture" (Schultz, 2011 $1_{[66]}$ ).

The business model of a coffeehouse is easy to imitate. While the Starbucks brand is a trademark, the Starbucks experience cannot be protected by intellectual property. The way Starbucks can stay ahead of competition is by constantly reviewing and improving its 
processes to make sure that the Starbucks experience remains unique, including by renewing some of the products or adjusting to changes in consumer behaviour (such as during COVID-19). The training and experience of employees (such as the knowledge of coffee and talent of baristas) is the asset that is more difficult for competitors to acquire. All employees in stores (including those on part-time jobs) receive health benefits and equity in the form of stock options, as a way to limit turnover.

For a chain with stores in multiple markets, it is also important to provide the same experience and maintain the same quality across locations, while still preserving the 'neighbourhood feel'. This is also done through the training of personnel, not only for company-operated stores but also for licensees. Stores then receive a local feel through their design (so that they do not all look the same) and by integrating local customs in the Starbucks experience.

Since preserving the culture of the company and focusing on details are at the centre of the business model, Starbucks prefers directly operating its stores. It guarantees that the values and processes of the company are respected. With limited exceptions in Europe (a market that was more difficult for the company to enter), Starbucks does not have franchises. Franchising is generally used in the food and beverage industry to quickly open new stores without having to raise capital (as the franchisees have to invest in stores and equipment). Instead, Starbucks favours licensing where the shops are still owned by Starbucks. ${ }^{23}$ Licensees pay royalties on their retail sales and are responsible for operating costs. Starbucks receives a margin on branded products and supplies sold to the licensed store. Employees of licensed stores have to follow the same training as employees in companyoperated stores. Starbucks generally signs licensing agreements with large companies (such as department stores, retail chains, bookstores, airports, etc.) with employees in stores working for these companies.

Another advantage of licensing is that Starbucks keeps some control on the location of stores and can open several in the same area (while franchising agreements generally have clauses granting exclusivity in a specific area). While it is surprising for consumers to see two Starbucks stores very close from each other, it is actually a profitable strategy in highly frequented places where long queues would affect the Starbucks experience and be detrimental to the reputation of the company.

\section{Intangible and tangible assets owned by Starbucks}

Starbucks relies on some of the intellectual property assets recorded in balance sheets and national accounts. It uses intellectual property mainly to protect its brand and products. Trademarks are registered in the United States and in other countries for Starbucks, the Starbucks logo but also for other brands such as Starbucks Reserve (a high-end type of stores) or Seattle's Best Coffee (a subsidiary of Starbucks) and for some products (e.g. the Frappuccino). The company owns copyrights on product packaging, promotional materials, in-store graphics and training materials. It also has patents on certain products, systems and designs. ${ }^{24}$ These intellectual property assets can be seen as elements of the Starbucks experience as they are part of the processes and training through which the company creates its customer experience. But the brand, the know-how, the connections with suppliers and customers are intangible elements not recorded and not valued.

As a consequence, the consolidated balance sheet of Starbucks includes a limited amount of intangible assets (782 million USD in 2019, i.e. 4\% of total net assets). Physical assets account for a much higher share with property, plant and equipment corresponding to one third of total net assets. Properties and plants include roasting and manufacturing facilities, warehousing and distribution locations, as well as leasehold improvements. Equipment is mostly roasting equipment, espresso machines and furniture in stores. However, this 
accounting does not reflect the value generated by these assets and the fact that the income of Starbucks is more related to the Starbucks experience than to the espresso machines and furniture used in the stores.

\section{Geographic coverage of Starbucks activities}

While Starbucks stores can be found in 81 countries or territories, the company has most of its income coming from the Americas (69\%). The region includes the United States, Canada and Latin America but the United States alone accounts for 15041 stores out of 18059 in the Americas (as of 2019). The second main market for Starbucks is Asia with 4123 stores in China, 1379 in Japan and 1334 in Korea. There is also a significant number of stores in Chinese Taipei (480), Indonesia (421), the Philippines (397) and Thailand (392). The Europe, Middle East and Africa segment accounts for a smaller share of income with the United Kingdom as main market ( 995 stores) followed by Turkey (494 stores). In China and Japan, Starbucks only has company-operated stores. But licensed stores are prevalent in other markets.

International licensing is an important economic phenomenon next to trade and FDI but is often overlooked due to the lack of data (Contractor, 2021 ${ }_{[67]}$ ). Royalties are recorded in trade in services statistics (as a service exported to the licensee) but the partnership between the licensing company and the licensee is generally not known and not captured in the analysis of GVCs. Licensing allows some companies to use intangible assets accumulated in others and is therefore important to understand the role of intangible capital in GVCs.

For company-operated stores outside of the United States, Starbucks has subsidiaries and is thus a traditional MNE with a network of foreign affiliates. The location of these affiliates follows the geography of the location of stores. Some affiliates also provide products and services to licensed stores and are thus present in fully licensed markets where Starbucks also works with independent companies for logistics and distribution. The network of affiliates may also be influenced by fiscal optimisation strategies. Tax avoidance of Starbucks in the United Kingdom was pointed out in 2012 with profit from UK stores transferred to an affiliate in the Netherlands (Campbell and Helleloid, 2016 ${ }_{[68]}$ ). However, in response to criticisms, Starbucks reorganised its network of subsidiaries in Europe and started to pay more taxes in the United Kingdom. ${ }^{25}$

\section{Starbucks in the coffee value chain}

The coffee value chain is an example of consumer-driven value chain where most of the income accrues to brands and retailers (Samper, Giovannucci and Vieira, 2017 $[69]$ ). According to a study by the Specialty Coffee Association, in a USD 2.80 brewed coffee cup, only 7 cents go to coffee growing. The cost of roasting is 35 cents while exporting and distribution account for 20 cents. All the rest (USD 2.17) goes to retail with a 44 cents mark-up. This mark-up is likely to be higher in coffeehouses and for more sophisticated products (e.g. lattes, mochas, etc.).

As the taste and aromas of coffee are part of the Starbucks experience, the company tries to control the whole value chain and does not outsource the supply of coffee beans or roasting activities. To make sure that its coffee tastes the same everywhere, Starbucks has six roasting facilities ( 5 in the United States and 1 in the Netherlands). For markets in Asia, it will open a new facility in China in 2022 as part of a Coffee Innovation Park that will also include a warehouse and distribution centre. ${ }^{26}$

For the sourcing of green coffee beans, Starbucks works directly with selected producers in Latin America, Asia and Africa. The company puts the emphasis on long-term relationships with coffee farmers and Coffee and Farmer Equity (C.AF.E.) practices. 
Starbucks has built Farmer Support Centres (FSC) next to some sourcing locations in order to implement high sustainability and ethical standards. ${ }^{27}$ This type of corporate social responsibility strategy is a requirement in the coffee industry as consumers are more and more attentive to fair trade and climate change. It is especially important for Starbucks, as the objective of the company is to connect to people.

While Starbucks maintains a high degree of control on its value chain, using vertical integration (including by distributing and selling the coffee in its own stores), it has entered into partnerships to reach consumers beyond coffeehouses. For example, Starbucks has agreements with PepsiCo, Inc., Anheuser-Busch InBev, Tingyi Holding Corp. and Arla Foods for the distribution of ready-to-drink beverages. In addition, since 2018, it has formed the Global Coffee Alliance with Nestlé and receives royalties for retail sales of coffee and other products under the Starbucks brand. This is another illustration of the use of the intangible asset created by Starbucks (the brand and its reputation) to sell products to consumers. Companies like Nestlé (the owner of Nespresso) also have the experience and the value chain to produce high quality coffee products. But they find it profitable to rely on the Starbucks brand and the Starbucks experience to reach consumers.

\subsection{Tata Consultancy Services}

Tata Consultancy Services (TCS) is an information technology (IT) company headquartered in Mumbai, India. Its business model relies on the fine-slicing of business functions and the shift towards the outsourcing of IT-related tasks that has been observed in many industries particularly since the late 1980s (Mudambi and Venzin, 2010 [70]; Lee, Park and Krishnan, 2014 [71]). The case of TCS illustrates the evolving role of trade in ITintensive services in global value chains. It also provides insight into the strategies employed by MNEs from emerging economies seeking to gradually capture more value from intangible capital.

TCS was established in 1968 as a division of the Tata group, a large Indian conglomerate whose origins can be traced back to the late $19^{\text {th }}$ century. ${ }^{28}$ The companies' activities cover a diverse set of IT-related services, including business process outsourcing and software development as well as consulting. TCS generated revenues of USD 21.5 billion in the fiscal year 2019-2020 and was the second-largest Indian company in terms of market capitalisation in September 2020. Contributing more than half of total revenue, the United States are by far the most important market for TCS. The United Kingdom $(15.9 \%$ of total revenue), India (5.7\%), China (3.9\%) as well as Germany (3.1\%) are further important markets for the company. ${ }^{29}$

TCS offers a wide range of IT-related services. Examples include data processing, the implementation of a new enterprise resource planning software, as well as the design of integrated software solutions tailored to specific business objectives. For a recent project with the Dutch shipbuilding group Damen, TCS developed an integrated vessel platform. It gathers information from 10 000-15 000 sensors per ship and facilitates the remote monitoring of performance indicators, such as fuel consumption. In the retail sector, the collaboration with the Australian supermarket group Woolworths encompasses projects dedicated to cloud-based solutions for data analysis and the automation of back-office tasks (TCS, 2020 $[72]$ ).

\section{Long-term relationships with customers and global delivery model}

IT consulting projects often involve access to sensitive data and the client frequently has to share details of its business processes. The customer's trust is therefore of paramount importance to TCS's business strategy and efforts to build long-term customer relationships 
can be regarded as an investment in an intangible asset. In the air transport sector, for example, TCS has been working with the airline network Star Alliance for more than 16 years, e.g. to ensure smooth baggage tracking across different carriers. In its annual report for fiscal year 2019-2020, TCS highlighted its special ties with 49 customers that each account for more than USD 100 million per year.

The company's capacity to coordinate the work of different teams across geographically distant locations constitutes a fundamental intangible asset underpinning its strategy. More than 450000 employees in 44 economies were on the company's payroll in September $2020{ }^{30}$ While codified information can now be easily transferred at negligible cost across large distances, the exchange of context-specific information and the establishment of trust is facilitated by geographical proximity (Storper and Venables, $\left.2004_{[73]}\right)$. IT consulting projects necessitate close coordination between the service provider and the customer. Similar to other major IT services consultancies, TCS has developed a global delivery model (GDM), i.e. a strategy that coordinates the tasks of geographically dispersed teams jointly contributing to the completion of a project. On the one hand, the GDM takes into account the benefits of geographical proximity in order to ensure smooth communication with the client. Subsidiaries in major markets, such as the United States and the United Kingdom, play an important role with respect to the identification of customers' priorities and the development of a strong relationship with the client (Kotlarsky, Scarbrough and Oshri, 2014[74]).

\section{Figure 3.4. TCS' network of foreign affiliates}
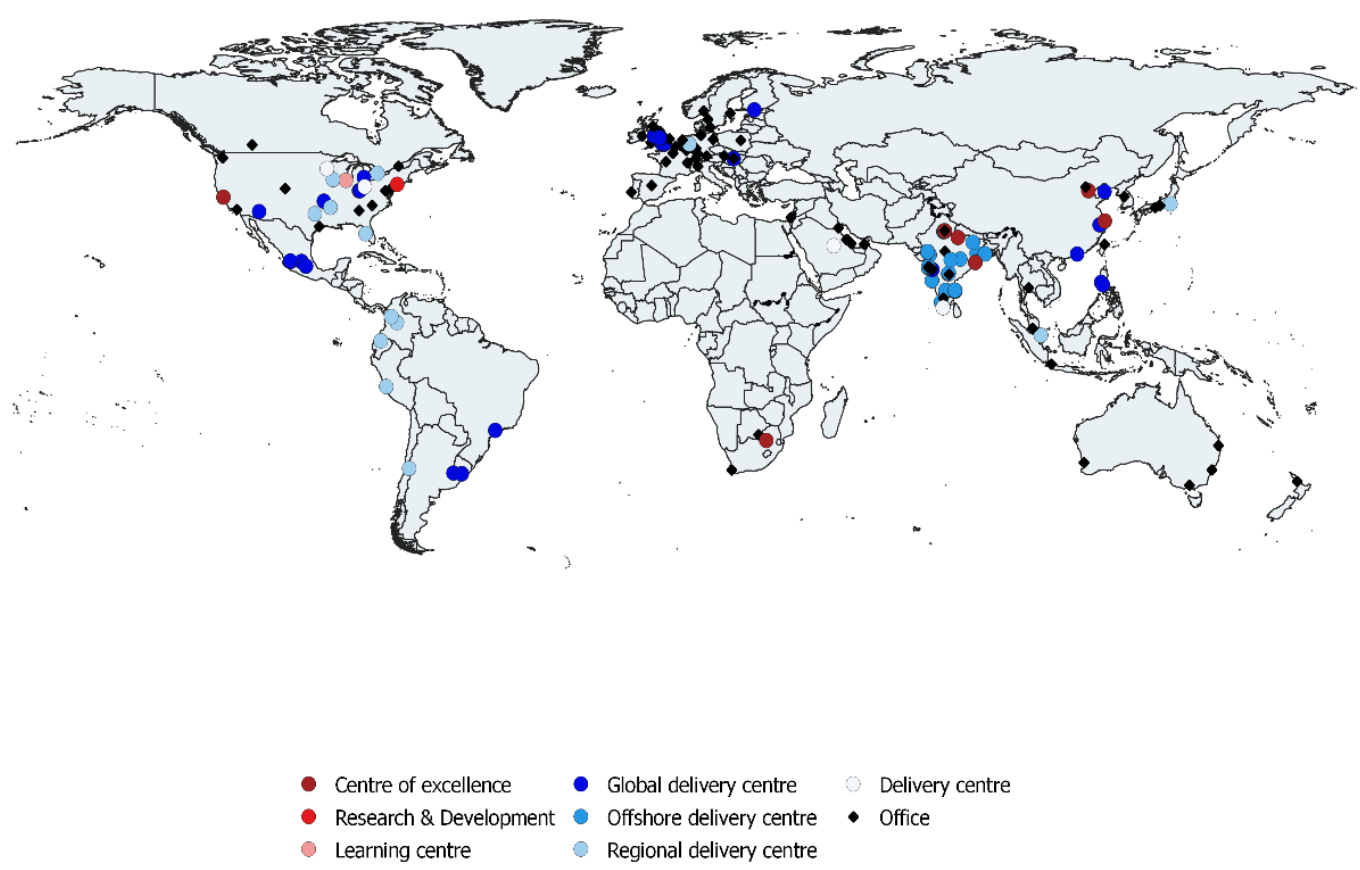

Source: Authors' illustration based on https://www.tcs.com/worldwide

On the other hand, the GDM allows the company to exploit and combine location-specific advantages regarding expertise and labour costs across a large portfolio of subsidiaries 
(Carmel, 2006 ${ }_{[75]}$; Manning, Larsen and Bharati, 2015[76]). Subsidiaries in so-called nearshore locations, such as regional delivery centres in Latin America (see Figure 3.4. TCS' network of foreign affiliates) enable TCS to limit transaction costs associated with different time zones and cultural and language barriers and also offer opportunities to limit labour costs (Lee, Park and Krishnan, 2014 $\left.{ }_{[71]}\right)$. Offshore delivery centres located in India are part of this network of affiliates characterised by different specialisations. For example, TCS employees in Guadalajara, Mexico, might support a project for a US client based close to the TCS subsidiary in Santa Clara, California. As part of this collaboration of different geographically dispersed units, a TCS team in Kolkata, India, may focus on tasks that are relatively labour-intensive but can be performed without being located in the client's time zone.

The capacity to operate such a globally integrated system for the delivery of IT services is a key characteristic of lead firms in the IT consulting industry. In addition to dividing large projects into tasks allocated to subsidiaries across different countries and time zones, lead firms also often outsource lower-value-added activities to lower-tier providers. The difficulty of implementing a GDM strategy is a considerable obstacle for new entrants seeking to compete with the lead firms for large projects focused on high value-added tasks (Kleibert and Mann, 2020 ${ }_{[77]}$ ). In the case of TCS, the value the company attributes to its GDM strategy is reflected in its efforts to protect its ownership of this intangible asset through formal intellectual property rights. For example, the company filed a patent application with the United States patent and trademark office dedicated to scalable and customisable location independent agile delivery models in December 2019.

\section{How to catch up as an MNE from an emerging economy}

The largest Indian IT consultancies, including TCS, are increasingly operating in higher value-added segments (Nathan, Sarkar and Mehta, 2017 $[78]$; Gereffi, 2019 $[79]$ ). ${ }^{31}$ As these service firms seek to climb the "smile curve" representing the uneven distribution of value capture across different stages of the value chain (Mudambi, 2008 ${ }_{[9]}$ ), they invest in the technological and managerial capabilities required for complex tasks at the intersection of IT services, management consulting and engineering services (Contractor, 2015 $[80]$ ).TCS has developed a set of standardised protocols and processes to manage and codify relevant knowledge in a coherent way across different teams and projects (Kotlarsky, Scarbrough and Oshri, 2014 $\left.{ }_{[74]}\right)$. In the context of rapid technological change, TCS invests in continuous training to adapt its employees' skills to new requirements (Mandavia, Mendonca and Krishnan, 2018 ${ }_{[81]}$ ). The company has simultaneously been expanding its patenting activities in recent years and was the top applicant for information technology patents at the Indian patent office during 2008-2018 (Mani, 2020 $[82]$ ). ${ }^{32}$

As firms rarely innovate in isolation, access to diverse sources of inspiration and external impulses acts as a major determinant of their capacity to create new economically valuable knowledge (Edquist, 2006 ${ }_{[83]}$ ). Leading multinational enterprises often tap into placespecific knowledge pools by creating "location portfolios" (Cantwell, 2009 ${ }_{[17]}$; Meyer, Mudambi and Narula, 2011 $1_{[18]}$ ). Such strategies can involve the establishment of dedicated units as "listening posts" in specific locations in order to identify emerging technological developments and gain access to intangible assets that could complement the company's existing knowledge base (Maskell, 2014 $\left.{ }_{[19]}\right)$. A case in points is the "co-innovation network" launched by TCS in 2006. It involves research institutes as well as start-ups and venture capital firms from different technology fields and sectors. The company collaborates with several universities, e.g. through an innovation centre at Cornell Tech campus in New York. Similarly, a strategic partnership with the University of Tokyo focused on embedded systems and robotics was announced in October $2020 .{ }^{33}$ 
MNEs from emerging economies, such as TCS, often rely on mergers and acquisitions in order to expand their ownership of knowledge assets (Howell, Lin and Worack, 2020 [84]). In the mid-2000s, acquisitions of Australian and Swiss firms enabled TCS to assemble a strategically valuable portfolio of IT solutions for financial services (Lee, Park and Krishnan, 2014[71]). More recently, the economic shock caused by the Covid-19 pandemic has forced many financial service providers to streamline their operations and created further opportunities for TCS to strengthen its position in this sector. In November 2020, TCS announced the acquisition of an IT-focused subsidiary of Deutsche Bank and an Ireland-based IT unit of the United States insurance company Prudential Financial. M\&A deals hence represent an important element of TCS' strategy to gain access to intangible assets and bolster its technological capabilities.

For MNEs from emerging economies, investments in knowledge assets are often primarily considered as efforts to close the technological gap with leading firms in advanced economies (Dunning, Kim and Park, 2008 ${ }_{[85]}$; Giuliani et al., 2014 ${ }_{[86]}$ ). Yet, TCS and other large Indian IT consulting firms also face considerable pressure to adapt their business model to changes in competitors' strategies and technological progress. Global delivery models combining geographically dispersed teams characterised by different skill profiles and labour costs were pioneered by Indian companies but are now widely used by most large IT consultancies. Similarly, many competitors from high-income economies now employ a large number of staff in India. In addition, the growing use of cloud-based solutions and artificial intelligence reduces the demand for the offshoring of routinised IT tasks. Against this backdrop, TCS' investments in intangible assets can also be considered as part of a defensive innovation strategy.

\section{The "ABCs" of GVC-oriented policies: further policy implications related to MNEs}

Relying on aggregate evidence and case studies, this report has highlighted the important role played by foreign affiliates of MNEs in the capture of value added in GVCs through intangible capital. As intangible assets represent an increasing share of income derived from global production and are key drivers of productivity and growth (Corrado, Hulten and Sichel, 2009 [87]; Jona-Lasinio and Meliciani, 2018 ${ }_{[88]}$ ), there is a need to identify trade, investment, innovation and industrial policies that can attract and retain intangible capital.

In a previous report (Van Assche, 2020 $0_{[2]}$ ), the concept of "ABCs" of GVC-oriented policies was introduced with three categories of policies described as: Attractiveness policies that aim to strengthen the appeal of a location for intangible activities; Buzz policies that intend to internally reinforce the local production and innovation ecosystem; and Connectedness policies that aspire to strengthen the connections of the local ecosystem to other locations. In this section, we revisit the $\mathrm{ABC}$ framework and add further policy implications related to the findings of this report on MNEs and intangible capital.

\subsection{Attractiveness}

The first finding of this report is that foreign affiliates account in all GVCs for a higher share of returns to intangible capital than their share of gross value added. This is explained by the fact that one motivation for firms to create affiliates that they own is to make sure that knowledge and technology remain within the boundaries of the firm. Foreign affiliates of MNEs also benefit from the intangible capital accumulated in their parent company and have a competitive advantage over domestic firms in the host economy.

While MNEs have incentives to prevent the diffusion of knowledge, there are nonetheless important spillovers from FDI. First, affiliates of MNEs have to interact with local firms 
and to share some of their knowledge with their suppliers and customers (Meyer, Mudambi and Narula, 2011 $\left.1_{[18]}\right)$. Foreign-owned firms source most of their inputs from domestic suppliers (Cadestin et al., 2018 ${ }_{[89]}$ ) and ensuring that their inputs seamlessly fit into the MNE production process requires some transfer of knowledge. The case studies have illustrated that MNEs are not just relying on FDI but have complex strategies that also involve cooperation and partnerships with local firms, particularly when it comes to R\&D.

Moreover, MNEs may also raise domestic firms' awareness of the value of intangible assets. Competition between domestic suppliers to be part of the MNE network can encourage their R\&D investments (Ruiz Durán, 2014[90]). Attracting affiliates of MNEs in the host economy should therefore be part of attractiveness policies.

Measures that governments can adopt start with an open and predictable investment environment both in terms of establishment and rules that apply post-establishment to the operations of foreign affiliates. Because of the complementarity between trade and investment in GVCs, an open trade regime is also required in addition to an open investment regime (Jaax and Miroudot, 2021 ${ }_{[91]}$ ). However, as highlighted in Van Assche $\left(2020_{[2]}\right)$, GVC-friendly interventions go beyond the scope of trade and investment policies and involve not only a stable business environment in which it is easy for companies to establish and operate business, but also creating high-quality institutions, developing an efficient and robust infrastructure and fostering a healthy innovation environment. This points to other policy areas that should receive extra attention when focusing on intangible capital, such as regulatory systems, intellectual property rights protection, financing and taxation. Only a whole-of-government or integrated approach can develop the enabling environment that will successfully attract innovative foreign firms.

While there are obvious benefits in attracting foreign MNEs in the domestic economy, some attention should also be given to risks and in particular those related to competition. Superior technology can also lead to market power and some sectors are also more prone to competition issues than others due to the structure of markets and characteristics of products. One of the case studies was in the digital sector where there is an ongoing debate on concentration and innovation (Cabral, 2020 [92]; Kamepalli, Rajan and Zingales, 2020 [93]; OECD, 2020[94]). It is important to address competition issues but through a better regulatory environment rather than by creating barriers to the entry of foreign firms. Foreign firms can even help to make markets contestable when the dominant firm is domestic.

\subsection{Buzz}

As highlighted in the FDI literature, spillovers from the presence of foreign firms are not automatic (Cohen and Levinthal, 1990 ${ }_{[22]}$ ) and within GVCs as well there is an absorptive capacity to be able to fully take part in the activities of MNEs and to be associated to their innovative processes (Fu, Pietrobelli and Soete, 2011 [95]; Pietrobelli and Rabellotti, $2011_{[23]}$. The case studies have illustrated that MNEs are quite selective in the location of their activities and that beyond the market size criteria, only selected cities are involved when it comes to R\&D activities, with a role also for the co-location of production and innovation (Belderbos et al., 2016 $6_{[96]}$ ). This is where place-based buzz policies become particularly important to reinforce the local production and innovation systems. Buzz policies generally focus on urban areas and aim at increasing the density of people and firms and strengthening network connections among local players to benefit from agglomeration economies (Glaeser and Gottlieb, 2009 ${ }_{[97]}$ ).

Such policies target by nature domestic firms and may include industrial policies providing support to new firms or to innovation. But one takeaway from the analysis in this report is 
that such policies should not introduce economic distortions with foreign-owned firms and should not aim at creating local capacity in a silo or independently from activities of foreign firms. On the contrary, the local capacity should be seen as a step to be able to benefit from connections with foreign MNEs.

Concretely, it means that networking policies involving formal and informal frameworks to facilitate private-private and public-private partnerships, cluster associations and programmes promoting collaboration between universities and private firms should be open to foreign affiliates of MNEs and encourage local linkages between domestic and foreign firms. This way, buzz policies can lead to global connectedness. They can strengthen the local production and innovation system to fully benefit from spillovers of the intangible capital of foreign affiliates.

\subsection{Connectedness}

In the case of activities of MNEs, connectedness policies are important not only to increase the returns to intangible capital in the host economy but also to attract foreign affiliates. There is an overlap in this case between attractiveness and connectedness. Global connectedness policies cover a range of measures related to trade facilitation, the development of an efficient and robust transportation structure, investment facilitation, the hassle-free movement of business persons, airport connectivity, efficient infrastructure services, fast telecoms systems providing interoperability, etc.

As highlighted in this report, foreign affiliates and their higher returns to intangible capital are found not only in the domestic economy but also in the global value chains of domesticowned and foreign-owned firms. While buzz policies can promote knowledge spillovers with the foreign firms established in the host economy, domestic firms can also benefit from spillovers with the MNE network and this requires global connectedness. Moreover, connectedness policies can also promote outward FDI and the expansion of domestic MNEs. One of the case studies has illustrated the challenges but also the benefits of GVCs for MNEs from emerging economies. The literature suggests that there are important learning effects from outward FDI with a higher productivity of domestic MNEs which is not limited to selection effects (Hejazi, Tang and Wang, 2020[98]]).

The way connectedness operates and helps countries to build their comparative advantage and innovate is not always easy to identify in aggregate data but the case studies have provided anecdotal evidence that some successful businesses or new products often start with a person travelling or the personal experience of an entrepreneur trying a foreign product. Business networks then play an important role in innovation and in the collaboration agreements and partnerships described in the case studies (Ozman, 2009 ${ }_{[99]}$; Öberg, 2019[100] $)$.

To conclude, one should stress that attractiveness, buzz and connectedness policies will be particularly important in the context of the economic recovery after the COVID-19 pandemic. As drivers of productivity and growth, intangible assets are key for countries to recover but also to build back better. If COVID-19 accelerates the reorganisation of GVCs and firms reassess the location of their activities, the policies described in this Section will play an important role in maintaining or attracting intangible-intensive activities. 


\section{Endnotes}

${ }^{1}$ Taxation and tax-related aspects of MNE activities are not discussed in detail in this paper, they are addressed in other strands of OECD work. Information and robustness checks on the impact of MNEs' fiscal optimisation strategies on the calculation of returns to intangible capital can be found in Alsamawi et al. $\left(2020_{[1]}\right)$.

${ }^{2}$ Based on the World Bank classification of economies in four groups (high income, upper-middle income, lower-middle income and low income). The dataset we use has no economy from the lowincome group.

${ }^{3}$ When Adidas was formally registered in 1949, its founder Adolf Dassler drew on the capabilities of a sportswear company he had set up with his brother, Rudolf Dassler, in the 1920s. Initially a small family business, it rapidly forged close links with leading athletes, for example by providing spikes to U.S. gold medallist Jesse Owens at the 1936 Olympics in Berlin. The two brothers fell out in the late 1940s and went their separate ways. Adolf Dassler registered Adidas in 1949 - a year after his brother Rudolf had established his sportswear company, Puma. Both companies are still headquartered in Herzogenaurach.

4 The company's modern strategy centred on the outsourcing of production and strong design and distribution capabilities was shaped by Robert-Louis Dreyfus, a French manager who was CEO of Adidas between 1993 and 2001. For a discussion of different waves of outsourcing in the sports shoe industry since the 1970 s, see Lechner et al. $\left(2020_{[36]}\right)$.

${ }^{5}$ For example, an accelerator programme for start-ups launched by Adidas in Paris in 2019 is expected to strengthen the company's capacity to develop digital business models.

${ }^{6}$ This average (293.8) refers to industrial designs registered during 2015-2019 that state Adidas or Reebok as the holder in the WIPO global design database. Regarding design registrations listing Nike as the holder, the average across the same period is 1503.6. It is 69.4 in the case of Puma.

${ }^{7}$ The company maintains an archive of approximately 40,000 products that can be used as a source of inspiration for the development of new designs (Newcomb, 2019 ${ }_{[111]}$ ).

8 The crucial role of access to innovative materials is illustrated by the tensions between Adidas and its competitor Puma over a synthetic damping material called expanded thermoplastic polyurethane (ETPU). BASF had collaborated with Puma on a project focused on a new foam polyurethane for shoe soles in the late 2000s but entered an exclusive partnership with Adidas in 2011. Drawing on ETPU, Adidas introduced its "Boost" shoes in 2013. Puma started a collaboration dedicated to polyurethane foam technology with U.S. company Huntsman Corp in 2014 and soon afterwards launched its own range of shoes ("NRGY") based on the synthetic material. The use of ETPU in shoe soles led to lengthy legal disputes between Adidas and Puma, with the two companies repeatedly accusing each other of IPR infringements (Hofer, 2016 $6_{[112]}$ ).

9 Turkey is the only OECD Member mentioned in the company's annual report 2019 as a major sourcing economy, it accounts for $18 \%$ of the total volume in the hardware category.

${ }^{10}$ In 2006 Adidas acquired Reebok, a large U.S. competitor, in an attempt to increase its share of the U.S. market and generate cost savings. The management of marketing and sales regarding the Reebok brand was kept separate from the management of the Adidas brand, but central functions (e.g. sourcing of materials, logistics, HR) are shared across the two brands.

${ }^{11}$ A strategic shift towards greater control of the distribution stage has similarly been described in the case of Adidas' competitor Nike (Carpenter, 2019 $[117]$ ). 
12 The importance of e-commerce relative to other distribution channels increased further in the context of the Covid-19 crisis, with Adidas reporting that online sales grew by $93 \%$ during the second quarter of 2020 .

${ }^{13}$ Drugs are called blockbusters when revenues from their sales are higher than USD 1 billion.

${ }^{14}$ Based on economies with available data.

${ }^{15}$ Such as the Food and Drug Administration (FDA) in the United States, the European Medicines Agency (EMA) in the European Union or the Pharmaceuticals and Medical Devices Agency (PMDA) in Japan.

${ }^{16}$ Source: company's website (https://www.rocket-internet.com/).

${ }^{17}$ Lean manufacturing was initially developed by Toyota and adopted in non-digital firms. There is now a lean digital management (Bain, 2019).

${ }^{18}$ https://thehustle.co/rocket-internet-like-work-startup-clone-factory/

${ }^{19}$ Starbucks 2019 Annual Report. All data reported are for 2019.

${ }^{20} \mathrm{CNN}, 5$ November 2020. https://www.nbc12.com/2020/11/05/starbucks-close-more-stores-duecovid-l

${ }^{21}$ Starbucks press release, 10 June 2020. https://stories.starbucks.com/press/2020/starbucks-totransform-us-store-portfolio-by-building-on-the-strength-of-digital-customer-relationships/

${ }^{22}$ Starbucks 2019 Annual Report.

${ }^{23}$ Starbucks does not own the properties, as almost all stores are leased. But the tenant is Starbucks and not the licensee.

${ }^{24}$ Starbucks 2019 Annual Report.

${ }^{25}$ Financial Times, 'Starbucks' European unit paid 2.8\% UK tax last year', 19 September 2018.

${ }^{26}$ Starbucks press release, 12 March 2020. https://stories.starbucks.com/press/2020/starbuckscoffee-innovation-park-in-china-extends-global-roasting-network/

${ }^{27}$ From Bean to Cup: Starbucks, Supply Chain, and Sustainability. https://arcg.is/1q8eur

${ }^{28}$ For an overview of TCS' history within the Tata conglomerate, see Goldstein $\left(2008_{[113]}\right)$ and Lanthier $\left(2018_{[114]}\right)$.

${ }^{29}$ These revenue statistics are based on TCS' annual report (TCS, 2020 [72] $)$ and on estimates of the financial data provider FactSet.

${ }^{30}$ While detailed data on employment by country are not available, media reports indicate that the company's employees in the United States accounted for roughly $12 \%$ of the total headcount in June 2020 (Gill, 2020 [115]).

${ }^{31}$ For an overview of the evolution of the Indian IT services industry, see Dossani and Kenney $\left(2009_{[16]}\right)$ and Lee et al. $\left(2014_{[71]}\right)$.

${ }^{32}$ As of March 31, 2020, TCS had applied for 5,216 patents cumulatively and been granted 1,341 patents (TCS, 2020 [72]).

${ }^{33}$ Moreover, TCS collaborates with the Institute of Network Science of Yale University on a project focused on the development of a blockchain-based infrastructure for offline data sharing. 


\section{References}

Adidas (2020), Annual Report 2019.

Ahn, A., B. Hall and K. Lee (eds.) (2014), Mexico: auto industry and patenting in a technological dependent economy, Edward Elgar Publishing, http://dx.doi.org/10.4337/9781782548058.00017.

Alsamawi, A. et al. (2020), "Returns to intangible capital in global value chains: New evidence on trends and policy determinants", OECD Trade Policy Papers, No. 240, OECD Publishing, Paris, https://dx.doi.org/10.1787/4cd06f19-en.

Barkai, S. (2016), Declining Labor and Capital Shares Simcha Barkai.

Baumann, O. et al. (2018), "Rocket Internet: Organizing a Startup Factory”, Journal of Organization Design, Vol. 7, p. 13, http://dx.doi.org/10.1186/s41469-018-0037-2.

Belderbos, R. et al. (2016), "Where to Locate Innovative Activities in Global Value Chains: Does Colocation Matter?”, OECD Science, Technology and Industry Policy Papers, No. 30, OECD Publishing, Paris, https://dx.doi.org/10.1787/5jlv8zmp86jg-en.

Belderbos, R. and J. Zou (2009), "Real options and foreign affiliate divestments: A portfolio perspective", Journal of International Business Studies, Vol. 40/4, pp. 600-620, http://dx.doi.org/10.1057/jibs.2008.108.

Berndt, E. et al. (2015), "Decline In Economic Returns From New Drugs Raises Questions About Sustaining Innovations", Health Affairs, Vol. 34/2, pp. 245-252, http://dx.doi.org/10.1377/hlthaff.2014.1029.

Bloom, N. et al. (2020), “Are Ideas Getting Harder To Find?”, American Economic Review, Vol. 110, pp. 1104-1144, http://dx.doi.org/10.1257/aer.20180338.

Buckley, P. and M. Casson (1976), Future of the Multinational Enterprise, Palgrave Macmillan.

Cabral, L. (2020), "Merger Policy in Digital Industries", Information Economics and Policy, p. 100866, http://dx.doi.org/10.1016/j.infoecopol.2020.100866.

Cadestin, C. et al. (2018), "Multinational enterprises and global value chains: the OECD analytical AMNE database", https://doi.org/https://doi.org/10.1787/d9de288d-en.

Cadestin, C. et al. (2018), "Multinational enterprises and global value chains: New Insights on the tradeinvestment nexus", OECD Science, Technology and Industry Working Papers, No. 2018/05, OECD Publishing, Paris, https://dx.doi.org/10.1787/194ddb63-en.

Cahen, F. and F. Borini (2020), "International Digital Competence", Journal of International Management, Vol. 26, p. 100691, http://dx.doi.org/10.1016/j.intman.2019.100691.

Campbell, K. and D. Helleloid (2016), "Starbucks: Social responsibility and tax avoidance", Journal of Accounting Education, Vol. 37, pp. 38-60, http://dx.doi.org/10.1016/j.jaccedu.2016.09.001.

Cantwell, J. (2009), "Location and the multinational enterprise", Journal of International Business Studies, Vol. 40/1, pp. 35-41, http://dx.doi.org/10.1057/jibs.2008.82. 
Cantwell, J. (1989), Technological Innovation and Multinational Corporations, Basil Blackwell.

Carmel, E. (2006), "Building your information systems from the other side of the world: How Infosys manages time zone differences", MISQ Executive, Vol. 5/1, pp. 43-53.

Carpenter, M. (2019), Shut Out by Shoe Giants, 'Mom and Pop' Stores Feel Pinched, https://www.nytimes.com/2019/06/18/business/shut-out-by-shoe-giants-mom-and-pop-stores-feelpinched.html.

Caselli, F. and J. Feyrer (2007), "The Marginal Product of Capital*”, The Quarterly Journal of Economics, Vol. 122, pp. 535-568, http://dx.doi.org/10.1162/qjec.122.2.535.

Caves, R. (1971), “International corporations: the industrial economics of foreign investment", Economica, Vol. 38/149, pp. 1-27.

Chen, L. et al. (2018), "The international penetration of ibusiness firms: Network effects, liabilities of outsidership and country clout”, Journal of International Business Studies, Vol. 50, pp. 172-192, http://dx.doi.org/10.1057/s41267-018-0176-2.

Chen, W. et al. (2017), Measuring the income to intangibles in goods production: a global value chain approach, https://ideas.repec.org/p/wip/wpaper/36.html.

Chesbrough, H. and H. Press (2003), Open Innovation: The New Imperative for Creating and Profiting from Technology, Harvard Business School Press, https://books.google.fr/books?id=4hTRWStFhVgC

Cohen, W. and D. Levinthal (1990), “Absorptive Capacity: A New Perspective on Learning and Innovation", Administrative Science Quarterly, Vol. 35/1, p. 128, http://dx.doi.org/10.2307/2393553.

Contractor, F. (2021), "The world economy will need even more globalization in the post-pandemic 2021 decade", Journal of International Business Studies forthcoming.

Contractor, F., Y. Yang and A. Gaur (2016), "Firm-specific intangible assets and subsidiary profitability: The moderating role of distance, ownership strategy and subsidiary experience", Journal of World Business, Vol. 51/6, pp. 950-964, http://dx.doi.org/10.1016/j.jwb.2016.09.002.

Corrado, C., C. Hulten and D. Sichel (2009), "INTANGIBLE CAPITAL AND U.S. ECONOMIC GROWTH", Review of Income and Wealth, Vol. 55/3, pp. 661-685, http://dx.doi.org/10.1111/j.14754991.2009.00343.x.

Corrado, C., C. Hulten and D. Sichel (2005), "Measuring Capital and Technology: An Expanded Framework", in Corrado, C., J. Haltiwanger and D. Sichel (eds.), Measuring Capital in the New Economy, University of Chicago Press, Chicago.

David, J., E. Henriksen and I. Simonovska (2014), The Risky Capital of Emerging Markets, http://dx.doi.org/10.3386/w20769.

Dedrick, J., K. Kraemer and G. Linden (2010), "Who profits from innovation in global value chains?: a study of the iPod and notebook PCs", Industrial and Corporate Change, Vol. 19/1, pp. 81-116, http://dx.doi.org/10.1093/icc/dtp032.

Deloitte Centre for Health Solutions (2019), Ten years on Measuring the returns from pharmaceutical innovation. 
Demirbag, M. and A. Yaprak (eds.) (2015), Punching above their weight: the sources of competitive advantage for emerging-market multinationals, Edward Elgar Publishing, http://dx.doi.org/10.4337/9781782545019.00010.

Dischinger, M. and N. Riedel (2011), "Corporate taxes and the location of intangible assets within multinational firms", Journal of Public Economics, Vol. 95/7-8, pp. 691-707, http://dx.doi.org/10.1016/j.jpubeco.2010.12.002.

Dossani, R. and M. Kenney (2009), "Service Provision for the Global Economy: The Evolving Indian Experience", Review of Policy Research, Vol. 26/1-2, pp. 77-104, http://dx.doi.org/10.1111/j.15411338.2008.00370.x.

DPI (2021), Investment Digest, Artificial Intelligence for Drug Discovery, Biomarker Development and Advanced R\&D Landscape, Overview 2020, https://analytics.deep-pharma.tech/reports/AI-PharmaInvestment-Digest.pdf.

Dunning, J., C. Kim and D. Park (2008), “Old Wine in New Bottles: A Comparison of Emerging-Market TNCs Today and Developed-Country TNCs Thirty Years Ago”, in Sauvant, K. (ed.), The Rise of Transnational Corporations from Emerging Markets. Threat or Opportunity?, Edward Elgar Publishing, http://dx.doi.org/10.4337/9781848441460.00017.

EC (2013), Synthèse du Rapport d'Enquête sur le Secteur Pharmaceutique.

Edquist, C. (2006), Systems of Innovation: Perspectives and Challenges, Oxford University Press, http://dx.doi.org/10.1093/oxfordhb/9780199286805.003.0007.

Engwall, L. and A. Hadjikhani (2014), "Internationalization of financial services in turbulent markets", International Business Review, Vol. 23/6, pp. 1035-1039, http://dx.doi.org/10.1016/j.ibusrev.2014.06.008.

Flores, M. et al. (2013), "P4 Medicine: How Systems Medicine Will Transform the Healthcare Sector and Society”, Personalized Medicine, Vol. 10, pp. 565-576, http://dx.doi.org/10.2217/pme.13.57.

Fu, X., C. Pietrobelli and L. Soete (2011), “The Role of Foreign Technology and Indigenous Innovation in the Emerging Economies: Technological Change and Catching-up", World Development, Vol. 39/7, pp. 1204-1212, http://dx.doi.org/10.1016/j.worlddev.2010.05.009.

Gereffi, G. (2019), "Economic upgrading in global value chains”, in Handbook on Global Value Chains, Edward Elgar Publishing, http://dx.doi.org/10.4337/9781788113779.00022.

GFG (2019), Annual Report.

Gill, P. (2020), Businsess Insider India. Nearly 80,000 Indians with H-1B visas work for TCS, Infosys and other Indian IT companies, https:/www.businessinsider.in/careers/news/tcs-infosys-cognizant-hcltech-employees-on-h1b-visa-in-us/articleshow/76638231.cms.

Giuliani, E. et al. (2014), "Emerging versus advanced country MNEs investing in Europe: A typology of subsidiary global-local connections", International Business Review, Vol. 23/4, pp. 680-691, http://dx.doi.org/10.1016/j.ibusrev.2013.06.002.

Glaeser, E. and J. Gottlieb (2009), "The Wealth of Cities: Agglomeration Economies and Spatial Equilibrium in the United States", Journal of Economic Literature, Vol. 47/4, pp. 983-1028, http://dx.doi.org/10.1257/jel.47.4.983. 
Gold, E. (2021), "The fall of the innovation empire and its possible rise through open science", Research Policy, Vol. 50/5, p. 104226, http://dx.doi.org/10.1016/j.respol.2021.104226.

Goldstein, A. (2008), "The Internationalization of Indian Companies: The Case of Tata", Centre for the Advanced Study of India Working Paper Series, Vol. no. 08-02, http://www.nomurafoundation.or.jp/en/wordpress/wp-content/uploads/2014/09/2007111314 Andrea_Goldstein.pdf.

Grubert, H. (2003), "Intangible Income, Intercompany Transactions, Income Shifting, and the Choice of Location”, National Tax Journal, Vol. 56/1, Part 2, pp. 221-242, http://dx.doi.org/10.17310/ntj.2003.1s.05.

Haskel, J. and S. Westlake (2018), Capitalism without capital, Princeton University Press.

Hejazi, W., J. Tang and W. Wang (2020), "Selection, learning, and productivity at the firm level: Evidence from Canadian outward FDI”, Journal of International Business Studies, Vol. 52/2, pp. 306-320, http://dx.doi.org/10.1057/s41267-020-00343-9.

Hennart, J. (2009), "Down with MNE-centric theories! Market entry and expansion as the bundling of MNE and local assets", Journal of International Business Studies, Vol. 40/9, pp. 1432-1454, http://dx.doi.org/10.1057/jibs.2009.42.

Hernández, H. et al. (2018), The 2018 EU Industrial R\&D Investment Scoreboard, Publications Office of the European Union.

Hofer, J. (2016), Handelsbatt online. A Battle for the Sole, https://www.handelsblatt.com/23537376.html.

Holtbrügge, D. and T. Schuster (2017), The Internationalization Strategy of Adidas., Rainer Hampp Verlag.

Howell, A., J. Lin and S. Worack (2020), "Going out to innovate more at home: Impacts of outward direct investments on Chinese firms' domestic innovation performance”, China Economic Review, Vol. 60 , p. 101404, http://dx.doi.org/10.1016/j.chieco.2020.101404.

ILO (2019), The global labour income share and distribution.

IQVIA (2020), Global Medicine Spending and Usage Trends.

Jaax, A. and S. Miroudot (2021), "Capturing value in GVCs through intangible assets: The role of the trade-investment-intellectual property nexus", Journal of International Business Policy, http://dx.doi.org/10.1057/s42214-020-00086-2.

Jona-Lasinio, C. and V. Meliciani (2018), "Productivity Growth and International Competitiveness: Does Intangible Capital Matter?”, Intereconomics, Vol. 53/2, pp. 58-62, http://dx.doi.org/10.1007/s10272018-0722-y.

Jorgenson, D. and Z. Griliches (1967), "The Explanation of Productivity Change", The Review of Economic Studies, Vol. 34, p. 249, http://dx.doi.org/10.2307/2296675.

Kamepalli, S., R. Rajan and L. Zingales (2020), “Kill Zone”, http://dx.doi.org/10.3386/w27146.

Katz, M. and C. Shapiro (1985), "Network Externalities, Competition, and Compatibility", The American Economic Review, Vol. 75, pp. 424-440, http://www.jstor.org/stable/1814809. 
Kleibert, J. and L. Mann (2020), "Capturing Value amidst Constant Global Restructuring? InformationTechnology-Enabled Services in India, the Philippines and Kenya", The European Journal of Development Research, Vol. 32/4, pp. 1057-1079, http://dx.doi.org/10.1057/s41287-020-00256-1.

Kogut, B. and N. Kulatilaka (1994), "Operating Flexibility, Global Manufacturing, and the Option Value of a Multinational Network”, Management Science, Vol. 40/1, pp. 123-139, http://dx.doi.org/10.1287/mnsc.40.1.123.

Kogut, B. and U. Zander (1993), "Knowledge of the Firm and the Evolutionary Theory of the Multinational Corporation”, Journal of International Business Studies, Vol. 24/4, pp. 625-645, http://dx.doi.org/10.1057/palgrave.jibs.8490248.

Kogut, B. and U. Zander (1992), "Knowledge of the Firm, Combinative Capabilities, and the Replication of Technology", Organization Science, Vol. 3/3, pp. 383-397, http://dx.doi.org/10.1287/orsc.3.3.383.

Kotlarsky, J., H. Scarbrough and I. Oshri (2014), "Coordinating Expertise Across Knowledge Boundaries in Offshore-Outsourcing Projects: The Role of Codification”, MIS Quarterly, Vol. 38/2, pp. 607-628, https://www.jstor.org/stable/26634943.

Lakdawalla, D. (2018), "Economics of the Pharmaceutical Industry", Journal of Economic Literature, Vol. 56, pp. 397-449, http://dx.doi.org/10.1257/jel.20161327.

Lanthier, P. (2018), “Tata becoming multinational: a long-term process", Entreprises et histoire, Vol. 90/1, p. 76, http://dx.doi.org/10.3917/eh.090.0076.

Lechner, C. et al. (2020), "Supplier evolution in global value chains and the new brand game from an attention-based view", Global Strategy Journal, Vol. 10/3, pp. 520-555, http://dx.doi.org/10.1002/gsj.1381.

Lee, K., T. Park and R. Krishnan (2014), "Catching-up or Leapfrogging in the Indian IT Service Sector: Windows of Opportunity, Path-creating, and Moving up the Value Chain", Development Policy Review, Vol. 32/4, pp. 495-518, http://dx.doi.org/10.1111/dpr.12065.

Lev, B. (2001), Intangibles : management, measurement, and reporting, Brookings Institution Press.

Malerba, F. (2005), "Sectoral systems of innovation: a framework for linking innovation to the knowledge base, structure and dynamics of sectors", Economics of Innovation and New Technology, Vol. 14/1-2, pp. 63-82, http://dx.doi.org/10.1080/1043859042000228688.

Malerba, F. and L. Orsenigo (1997), “Technological Regimes and Sectoral Patterns of Innovative Activities", Industrial and Corporate Change, Vol. 6/1, pp. 83-118, http://dx.doi.org/10.1093/icc/6.1.83.

Mandavia, M., J. Mendonca and R. Krishnan (2018), The Economic Times online. Digital will be one-third of our revenues in 24 months: Rajesh Gopinathan, CEO, TCS., https://economictimes.indiatimes.com/tech/ites/digital-will-be-one-third-of-our-revenues-in-24months-rajesh-gopinathan-ceo-tcs/articleshow/63103406.cms.

Mani, S. (2020), “India's patenting record since TRIPS compliance of her patent regime”, Asian Journal of Technology Innovation, pp. 1-28, http://dx.doi.org/10.1080/19761597.2020.1829977.

Manning, S., M. Larsen and P. Bharati (2015), "Global delivery models: The role of talent, speed and time zones in the global outsourcing industry", Journal of International Business Studies, Vol. 46/7, pp. 850-877, http://dx.doi.org/10.1057/jibs.2015.14. 
Maskell, P. (2014), “Accessing remote knowledge--the roles of trade fairs, pipelines, crowdsourcing and listening posts”, Journal of Economic Geography, Vol. 14/5, pp. 883-902, http://dx.doi.org/10.1093/jeg/lbu002.

McMeekin, P. et al. (2020), "Schrödinger's Pipeline and the Outsourcing of Pharmaceutical Innovation", Drug Discovery Today, Vol. 25, pp. 480-484, http://dx.doi.org/10.1016/j.drudis.2019.11.015.

Meyer, K., R. Mudambi and R. Narula (2011), "Multinational Enterprises and Local Contexts: The Opportunities and Challenges of Multiple Embeddedness", Journal of Management Studies, Vol. 48/2, pp. 235-252, http://dx.doi.org/10.1111/j.1467-6486.2010.00968.x.

Michelli, J. (2007), The Starbucks Experience: 5 Principles for Turning Ordinary into Extraordinary, American Media International.

Mudambi, R. (2008), "Location, control and innovation in knowledge-intensive industries", Journal of Economic Geography, Vol. 8/5, pp. 699-725, http://dx.doi.org/10.1093/jeg/lbn024.

Mudambi, R. (2007), “Offshoring: Economic Geography and the Multinational Firm”, Journal of International Business Studies, Vol. 38/1, p. 206, https://www.jstor.org/stable/4540411?seq=1\#metadata_info_tab_contents.

Mudambi, R. and M. Venzin (2010), "The Strategic Nexus of Offshoring and Outsourcing Decisions", Journal of Management Studies, Vol. 47/8, pp. 1510-1533, http://dx.doi.org/10.1111/j.14676486.2010.00947.x.

Nathan, D., S. Sarkar and B. Mehta (2017), “Indian IT Firms: The Push for Innovation”, in Elms, D., A. Hassani and P. Low (eds.), The Intangible Economy: How Services Shape Global Production and Consumption, Cambridge University Press.

Newcomb, T. (2019), Inside The Adidas Archives In Germany: The White Glove Treatment For 40,000 Meaningful Products, https://www.forbes.com/sites/timnewcomb/2019/11/21/inside-the-adidasarchives-in-germany-the-white-glove-treatment-for-meaningful-product/.

Nordås, H. et al. (2014), "Services Trade Restrictiveness Index (STRI): Audio-visual Services", $O E C D$ Trade Policy Papers, No. 174, OECD Publishing, Paris, https://dx.doi.org/10.1787/5jxt4nj4fc22-en.

Öberg, C. (2019), "The role of business networks for innovation", Journal of Innovation \& Knowledge, Vol. 4/2, pp. 124-128, http://dx.doi.org/10.1016/j.jik.2017.10.001.

OECD (2020), "Start-ups, Killer Acquisitions and Merger Control - Background Note", OECD, Directorate for Financial and Enterprise Affairs Competition Committee, Vol. DAF/COMP(2020)5^.

OECD (2018), Pharmaceutical Innovation and Access to Medicines, https://doi.org/10.1787/9789264307391-en.

OECD (2013), Supporting Investment in Knowledge Capital, Growth and Innovation, OECD Publishing, Paris, https://dx.doi.org/10.1787/9789264193307-en.

Ozman, M. (2009), "Inter-firm networks and innovation: a survey of literature", Economics of Innovation and New Technology, Vol. 18/1, pp. 39-67, http://dx.doi.org/10.1080/10438590701660095.

Pietrobelli, C. and R. Rabellotti (2011), "Global Value Chains Meet Innovation Systems: Are There Learning Opportunities for Developing Countries?”, World Development, Vol. 39/7, pp. 1261-1269, http://dx.doi.org/10.1016/j.worlddev.2010.05.013. 
Pionnier, P. and E. Guidetti (2015), "Comparing profit shares in value-added in four OECD countries", https://doi.org/10.1787/5js0bsm2g0lt-en.

Ries, R. (2011), Lean Startup, Penguin.

Rocket Internet (2019), Annual Report.

Rouzet, D. et al. (2014), "Services Trade Restrictiveness Index (STRI): Financial Services”, OECD Trade Policy Papers, No. 175, OECD Publishing, Paris, https://dx.doi.org/10.1787/5jxt4nhssd30-en.

Rugman, A. (1981), Inside the multinationals: The economics of internal markets, Columbia University Press.

Samper, L., D. Giovannucci and L. Vieira (2017), "The powerful role of intangibles in the coffee value chain”, WIPO Economic Research Working Paper 39.

Scannell, J. et al. (2012), "Diagnosing the Decline in Pharmaceutical R\&d Efficiency", Nature Reviews Drug Discovery, Vol. 11, pp. 191-200, http://dx.doi.org/10.1038/nrd3681.

Schreyer, P., T. Cho and S. Hwang (2017), "Has the Labour Share Declined? It Depends", OECD Statistics Working Papers 77, http://dx.doi.org/10.1787/18152031.

Schuhmacher, A., O. Gassmann and M. Hinder (2016), "Changing R\&D models in research-based pharmaceutical companies”, Journal of Translational Medicine, Vol. 14/1, http://dx.doi.org/10.1186/s12967-016-0838-4.

Schultz, H. (2011), Onward: How Starbucks Fought For Its Life without Losing Its Soul, Wiley.

Stöllinger, R. (2021), "Testing the Smile Curve: Functional Specialisation and Value Creation in GVCs", Structural Change and Economic Dynamics, Vol. 56, pp. 93-116, http://dx.doi.org/10.1016/j.strueco.2020.10.002.

Storper, M. and A. Venables (2004), "Buzz: face-to-face contact and the urban economy", Journal of Economic Geography, Vol. 4/4, pp. 351-370, http://dx.doi.org/10.1093/jnlecg/lbh027.

Sturgeon, T., J. Van Biesebroeck and G. Gereffi (2008), "Value chains, networks and clusters: reframing the global automotive industry", Journal of Economic Geography, Vol. 8/3, pp. 297-321, http://dx.doi.org/10.1093/jeg/lbn007.

Sudarsanam, S., G. Sorwar and B. Marr (2006), "Real options and the impact of intellectual capital on corporate value”, Journal of Intellectual Capital, Vol. 7/3, pp. 291-308, http://dx.doi.org/10.1108/14691930610681410.

TCS (2020), Tata Consultancy Services Annual Report 2019-2020, https://on.tcs.com/Annual-Report$\underline{2020 .}$.

Timmer, M. et al. (2019), "EU KLEMS database", Economic Growth in Europe, pp. 46-128, http://dx.doi.org/10.1017/cbo9780511762703.004.

UNCTAD (2017), World Investment report 2017 - Investment and the Digital Economy.

Van Assche, A. (2020), "Trade, investment and intangibles: The ABCs of global value chain-oriented policies", OECD Trade Policy Papers, No. 242, OECD Publishing, Paris, https://dx.doi.org/10.1787/750f13e6-en. 


\section{4 | MULTINATIONAL ENTERPRISES AND INTANGIBLE CAPITAL}

Villalonga, B. (2004), “Intangible resources, Tobin's q, and sustainability of performance differences", Journal of Economic Behavior \& Organization, Vol. 54/2, pp. 205-230, http://dx.doi.org/10.1016/j.jebo.2003.07.001.

Wang, W. and Q. Sun (2020), "Novel targeted drugs approved by the NMPA and FDA in 2019", Signal Transduction and Targeted Therapy, Vol. 5/1, http://dx.doi.org/10.1038/s41392-020-0164-4.

Wong, C., K. Siah and A. Lo (2018), "Estimation of Clinical Trial Success Rates and Related Parameters", Biostatistics, Vol. 20, pp. 273-286, http://dx.doi.org/10.1093/biostatistics/kxx069.

Wong, W. (2019), Automotive Global Value Chain. The Rise of Mega Suppliers, Routledge. 


\section{Annex A. Methodology for the estimation of returns to intangible capital in GVCs and their foreign affiliates}

This Annex describes the methodology used for the estimation of returns to intangible capital in domestic-owned and foreign-owned firms at the industry level. These estimates rely on the database described in Alsamawi et al. $\left(2020_{[1]}\right)$. The reader can refer to this previous report for more detailed information on the way returns to intangible capital are calculated.

The underlying data for this exercise are the OECD Inter-Country Input-Output (ICIO) tables. Based on national accounts, these tables include transactions for 64 economies plus a 'rest of the world' and cover 36 industries classified in the International standard industrial classification (ISIC) revision 4 over the period 2005-2015. ${ }^{1}$

The tables provide detailed information on value added and output across countries/territories and industries but they do not break down value added into returns to the different primary factors of production. This extra step was added in the work carried out in Alsamawi et al. $\left(2020_{[1]}\right)$ in order to estimate returns to intangible capital in GVCs.

\section{Decomposition of gross value added to estimate returns to intangible capital}

The concept of gross domestic product (GDP) is not part of the OECD ICIO tables but they provide the gross value added (GVA), which is simply GDP without taxes minus subsidies on production. As for GDP, GVA can be defined based on a production approach, income approach or expenditure approach. Following the income approach in the System of National Accounts, GVA can be defined as the sum of labour compensation, gross operating surplus and gross mixed income, and taxes minus subsidies on products. We collect data on these different components in national accounts, using the same sources as for the construction of the ICIO tables.

In order to clearly distinguish income going to labour and capital, we split the gross mixed income into a part going to labour compensation and a part staying in the gross operating surplus (and thus going to capital). We thus decompose GVA into labour compensation, gross operating surplus (returns to capital) and taxes minus subsidies on products.

\section{Estimation of the part of gross mixed income allocated to labour compensation}

The gross mixed income includes the income generated by self-employment and is estimated differently across countries (Pionnier and Guidetti, $\left.2015_{[101]}\right)$. Cho, Hwang and Shreyer $\left(2017_{[102]}\right)$, as well as ILO $\left(2019_{[103]}\right)$, review the different methods that can be used to split it into labour and capital components. The preferred method is to use data on employment or self-employment by sector (from Labour Force Surveys for example). Otherwise, another method consists in reallocating the gross mixed income to labour and capital using a fixed share (generally $2 / 3$ to labour).

We reallocate a share of the gross mixed income to labour using data on self-employment from the WIOD database or from ILO. For countries or territories without such data, we use a reallocation based on a fixed share (2/3). Table A.1 indicates the method that was used for each country or territory in the dataset. 
Table A.1. Sources for the adjustment of labour shares

\begin{tabular}{l|l}
\hline \multicolumn{1}{c|}{ Methodology } & \multicolumn{1}{c}{ Countries/Territories } \\
\hline $\begin{array}{l}\text { No reallocation (no data } \\
\text { available) }\end{array}$ & Chinese Taipei. \\
\hline $\begin{array}{l}\text { Reallocation of a fixed } \\
\text { share of mixed income } \\
\text { (source: UNSD) }\end{array}$ & $\begin{array}{l}\text { Brunei Darussalam; Cambodia; Hong Kong (China); Kazakhstan; } \\
\text { Malaysia; Morocco; New Zealand; Peru; Philippines; Saudi } \\
\text { Arabia; Singapore; Thailand; Tunisia; Viet Nam. }\end{array}$ \\
\hline $\begin{array}{l}\text { Reallocation based on } \\
\text { data on self-employment } \\
\text { (source: ILO) }\end{array}$ & $\begin{array}{l}\text { Argentina; Chile; Colombia; Costa Rica; Iceland; Israel; South } \\
\text { Africa. }\end{array}$ \\
\hline $\begin{array}{l}\text { Reallocation based on } \\
\text { data on self-employment } \\
\text { (source: WIOD) }\end{array}$ & $\begin{array}{l}\text { Australia; Austria; Belgium; Brazil; Bulgaria; Canada; China } \\
\text { (People's Republic of); Croatia; Czech Republic; Denmark; } \\
\text { Estonia; Finland; France; Germany; Greece; Hungary; India; }\end{array}$ \\
$\begin{array}{l}\text { Indonesia; Ireland; Italy; Japan; Korea; Latvia; Lithuania; } \\
\text { Luxembourg; Malta; Mexico; Netherlands; Norway; Poland; } \\
\text { Portugal; Romania; Russia; Slovak Republic; Slovenia; Spain; } \\
\text { Sweden; Switzerland; Turkey; United Kingdom; United States. }\end{array}$ \\
\hline
\end{tabular}

\section{Returns to tangible capital}

Returns to tangible capital are estimated based on data on capital stocks, an ex-ante rate of return and depreciation rates. Following Jorgensen and Griliches $\left(1967_{[104]}\right)$, these returns can be calculated as: $p K=q *\left(r+\delta-\frac{\dot{q}}{q}\right)$ where $\mathrm{p}$ is the service price of capital, $\mathrm{K}$ is the stock of capital, $r$ is the internal rate of return, delta is the depreciation rate and $q$ is the price of investment, $\frac{\dot{q}}{q}$ is the capital gain that we assume to be zero. This equation links the service price of capital - i.e. income to capital - with the price of investment, the rate of return and the depreciation rate.

Data on capital stocks by industry and by type of asset are collected from the OECD Annual National Accounts (Table 9A). For non-OECD Members, we use similar data from the KLEMS projects or from national statistical offices. However, not all countries and territories produce capital stocks by industry and by type of asset. We create estimates using the Penn World Tables (version 9.1) for some of them.

The Penn World Tables have capital stocks not disaggregated by industry or by type of asset. We run a Poisson regression on sectors and asset dummies and on asset classes and income groups based on GDP per capita to allocate capital stocks across industries and asset types. A RAS algorithm is used for the sum of assets across industries to be equal to the total capital stock.

Following the SNA (2008) classification, assets are categorised as tangible or intangible. ${ }^{2}$

In perfectly competitive markets, the rate of return on capital is equal to the marginal product of capital. But the literature identifies differences across economies and in particular finds higher returns in developing economies (Caselli and Feyrer, 2007 [105]; David, Henriksen and Simonovska, 2014 ${ }_{[106]}$; Timmer et al., 2019 $\left.{ }_{[107]}\right)$. The rate of return can also be estimated via the cost of debt and equity (Barkai, 2016 $[108]$ ). We follow this later method with data from the IMF on lending rates and data from the World Development Indicators on inflation. We calculate the real internal rate of return as the lending rate minus inflation rate for three groups of economies. The average rates of returns in these groups are: $3.6 \%$ (developed economies), $4.5 \%$ (emerging economies) and 5.6\% (developing economies). 
Finally, we use the depreciation rates from the EU KLEMS database. They differ across industries and sectors but not across economies.

Our methodology to estimate returns to tangible capital is similar to Chen et al. $\left(2017_{[109]}\right)$ with the only difference being that instead of a rate of return equal to $4 \%$ for all economies, we use three different rates for developed, emerging and developing economies. It is justified by the fact that our dataset covers a broader set of economies and includes more developing economies where the $4 \%$ rate would underestimate returns to tangible capital.

\section{Returns to intangible capital}

As in Chen et al. $\left(2017_{[109]}\right)$, returns to intangible capital are then calculated as a residual by removing from the (adjusted) gross operating surplus returns to tangible capital. An additional adjustment is made for natural resources that generate income captured in GVA but without a corresponding asset. We use data from the World Bank on the rents derived from natural resources (from coal, forests, mineral, natural gas and oil) to calculate returns to natural resources (and to not include them in estimates of returns to intangible capital). This adjustment is, however, only relevant for the primary sector and oil industry.

In Alsamawi et al. $\left(2020_{[1]}\right)$, there is a distinction between 'measured' intangible capital and 'unmeasured' intangible capital. Consistent with SNA 2008, our dataset on capital stocks by asset type has data on capital stocks of intangible assets recorded in national accounts, corresponding to 'R\&D', 'mineral exploration and evaluation', 'computer software and databases' and 'entertainment, literary or artistic originals'. Assuming an average ex-ante rate of return of $4 \%$, it is possible to estimate returns to measured intangible capital. The residual then corresponds to intangible assets that are not captured in national accounts (such as brands or organisational capital) that we can regard as returns to 'unmeasured' intangible capital. In this report, we are not relying on this distinction as we cannot implement it for domestic-owned and foreign-owned firms.

\section{Returns to intangible capital for domestic-owned and foreign-owned firms}

The methodology to calculate returns to intangible capital for domestic-owned and foreignowned firms is similar to what was described before but requires additional data on the output, value added, trade and accumulation of labour and capital by domestic-owned and foreign-owned firms. For output, value added and trade, we find these data in the OECD Analytical AMNE database, which is an extension of the OECD ICIO tables where data are split according to the ownership of firms. A full description of this dataset can be found in Cadestin et al. $\left(2018_{[110]}\right)$. It provides all the data we need to split GVA between domestic-owned firms and foreign-owned firms for all the countries, industries and years included in the 'trade, investment and intangibles' dataset.

\section{Factor intensities for domestic-owned and foreign-owned firms}

We expect domestic-owned and foreign-owned firms to no use the same amount of labour, tangible and intangible capital in their production process. To capture differences in the ratios of labour compensation to GVA, tangible capital to GVA and intangible capital to GVA (i.e. factor intensities), we use micro-data from the Orbis database.

These data highlight different patterns for foreign affiliates of MNEs and for domesticowned firms. Domestic-owned firms are more intensive in labour while foreign affiliates are more intensive in capital (Table A.2). On average, the intangible capital stock of foreign affiliates is 1.72 times larger than the intangible capital stock of domestic-owned firms. 
Table A.2. Ratios of factor intensity between foreign affiliates and domestic-owned firms Factor intensity of foreign-owned firms divided by factor intensity of domestic-owned firms

\begin{tabular}{|c|c|c|c|}
\hline & $\begin{array}{c}\text { Labour compensation / } \\
\text { GVA }\end{array}$ & $\begin{array}{c}\text { Tangible capital / } \\
\text { GVA }\end{array}$ & $\begin{array}{c}\text { Intangible capital / } \\
\text { GVA }\end{array}$ \\
\hline Agriculture & 1.03 & 1.06 & 1.58 \\
\hline Mining (energy) & 0.93 & 1.03 & 2.13 \\
\hline Mining (non-energy) & 0.93 & 1.03 & 2.13 \\
\hline Services to mining & 0.93 & 1.03 & 2.13 \\
\hline Food products & 0.91 & 1.14 & 1.88 \\
\hline Textiles \& apparel & 0.98 & 1.06 & 1.67 \\
\hline Wood & 0.97 & 1.15 & 2.31 \\
\hline Paper and printing & 0.98 & 1.18 & 1.55 \\
\hline Coke, petroleum & 0.98 & 1.21 & 2.09 \\
\hline Chemicals & 0.95 & 1.19 & 1.43 \\
\hline Rubber \& plastics & 0.98 & 1.07 & 1.43 \\
\hline Non-metal minerals & 0.95 & 1.14 & 1.94 \\
\hline Basic metals & 0.94 & 1.25 & 1.48 \\
\hline Fabricated metals & 0.99 & 1.04 & 2.00 \\
\hline ICT \& electronics & 1.04 & 1.01 & 1.17 \\
\hline Electrical machinery & 1.00 & 1.12 & 1.42 \\
\hline Machinery & 0.99 & 1.01 & 1.38 \\
\hline Motor vehicles & 0.96 & 1.06 & 1.45 \\
\hline Other transport equip. & 0.98 & 1.08 & 1.38 \\
\hline Manufacturing nec; repair & 1.01 & 0.89 & 1.86 \\
\hline $\begin{array}{l}\text { Electricity; gas; water; } \\
\text { waste }\end{array}$ & 0.93 & 1.08 & 1.82 \\
\hline Construction & 1.00 & 0.86 & 2.01 \\
\hline Wholesale \& retail trade & 1.00 & 0.75 & 1.63 \\
\hline Transport & 1.06 & 0.79 & 2.03 \\
\hline Hotels \& restaurants & 0.98 & 1.08 & 1.87 \\
\hline Publishing; broadcasting & 1.06 & 0.69 & 2.13 \\
\hline Telecoms & 0.88 & 1.08 & 1.76 \\
\hline IT services & 1.12 & 0.67 & 1.35 \\
\hline Finance \& insurance & 0.93 & 0.78 & 1.78 \\
\hline Real estate & 0.94 & 0.99 & 1.49 \\
\hline Other business services & 1.06 & 0.69 & 1.73 \\
\hline Public administration & 1.11 & 0.52 & 0.44 \\
\hline Education & 1.05 & 0.71 & 1.76 \\
\hline Health & 1.00 & 0.94 & 2.01 \\
\hline Personal services & 0.98 & 1.08 & 1.82 \\
\hline
\end{tabular}

Source: Orbis

\section{Estimation of factor income for domestic-owned and foreign-owned firms}

We calculate factor intensities for domestic-owned and foreign-owned firms at the country, industry and year level using the ORBIS database for a sample of countries where this information is widely available ${ }^{3}$. We keep observations with at least 200 non-missing firms, with data for the three factors of production (labour, tangible capital and intangible capital) and with a stable number of observations across years (we remove observations where the sample differs by more than $15 \%$ in terms of number of firms). We then replace missing values with the information available from other countries (following rules similar to those used in the construction of the Analytical AMNE database). 
The balancing process is then the following. We remove from gross value added natural rents and taxes minus subsidies on products (split proportionally across domestic-owned and foreign-owned firms) to obtain $\dot{g} \bar{v} a$.

For each factor of production (labour, tangible capital and intangible capital), we then calculate the objective returns. For example, for labour compensation (labr) in year $y$, country $c$, industry $i$ and type of ownership $o$ (D for domestic and $\mathrm{F}$ for foreign), we calculate:

$$
\begin{aligned}
l a b r_{y, c, i}^{T I I}= & l a b r_{y, c, i, D}^{O B J}+l a b r_{y, c, i, F}^{O B J} \\
& \frac{l a b r_{y, c, i, D}}{g v a_{y, c, i, D}} * \widetilde{g v} a_{y, c, i, D}^{A A M N E}+\frac{l a b r_{y, c, i, F}}{g v a_{y, c, i, F}} * \widetilde{g v} a_{y, c, i, F}^{A A M N E}
\end{aligned}
$$

where $\lambda^{\text {labr,ORBIS }}$ is the ratio of labour intensity of foreign affiliates to domestic-owned firms as in Table A.2:

$$
\lambda_{\mathrm{y}, \mathrm{c}, \mathrm{i}}^{\mathrm{labr}, \mathrm{ORBIS}} \frac{\frac{l a b r_{y, c, i, F}^{O R B I S}}{g v a_{y, c, i, F}^{O R B I S}}}{\frac{\operatorname{labr} r_{y, c, i, D}^{O R B I S}}{g v a_{y, c, i, D}^{O R B I S}}}
$$

Rearranging the equation, we get an estimate of labour compensation for domestic-owned and foreign-owned firms based on the three data sources.

$$
\begin{aligned}
& l a b r_{y, c, i, D}^{O B J}=\quad l a b r_{y, c, i}^{T I I} * \frac{1}{1+\lambda_{y, c, i}^{l a b r, O R B I S} * \frac{\widetilde{g v} a_{y, c, i, F}^{A A M E}}{\widetilde{g v} a_{y, c, i, D}^{A A M N E}}} \\
& l a b r_{y, c, i, F}^{O B J}=\quad l a b r_{y, c, i}^{T I I}-l a b r_{y, c, i, D}^{O B J}
\end{aligned}
$$

We calculate the objective returns to tangible capital and objective returns to intangible capital in the same way to obtain $r K T_{y, c, i, d}^{O B J}$ and $r K I_{y, c, i, d}^{O B J}$.

Lastly, we use an optimisation to balance the data. The starting values are based on the proportional allocation of labour compensation, tangible capital and intangible capital based on the share of foreign-owned firms and domestic-owned firms in GVA. We minimise the square difference between the starting labour compensation, returns to tangible and intangible capital and their objective values.

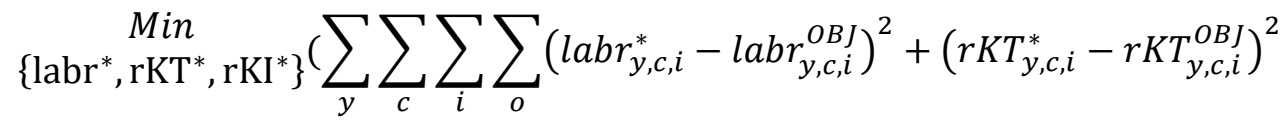

$$
\begin{aligned}
& \left.+\left(r K I_{y, c, i}^{*}-r K I_{y, c, i}^{O B J}\right)^{2}\right) \\
& \begin{aligned}
\mathrm{s} / \mathrm{t} \quad & \sum_{O} l a b r_{y, c, i, o}^{*}+r K T_{y, c, i, o}^{*}+r K I_{y, c, i, o}^{*}=\widetilde{g} \widetilde{v} a_{y, c, i}^{T I I} \\
& \sum_{o} l a b r_{y, c, i, o}^{*}=l a b r_{y, c, i}^{T I I}
\end{aligned}
\end{aligned}
$$


$\mathbf{5 0} \mid$ MULTINATIONAL ENTERPRISES AND INTANGIBLE CAPITAL

$$
\begin{aligned}
& \sum_{o} r K T_{y, c, i, o}^{*}=r K T_{y, c, i}^{T I I} \\
& \sum_{o} r K I_{y, c, i, o}^{*}=r K I_{y, c, i}^{T I I}
\end{aligned}
$$




\section{Endnotes Appendix A}

\footnotetext{
${ }^{1}$ See https://www.oecd.org/sti/ind/inter-country-input-output-tables.htm for more information.

2 Tangible capital includes the following categories: AN111, AN112, AN1131, AN11321, AN11322, AN1133_AN114, AN115.

${ }^{3}$ BEL, BGR, CZE, DEU, DNK, ESP, FIN, FRA, GBR, ITA, KOR, NLD, NOR, PRT, ROU, SVK, SVN.
} 


\section{Annex B. Methodology to distinguish purely domestic production from international production in returns to intangible capital}

The Analytical AMNE database includes Inter-Country Input-Output tables with $N=60$ countries (59 plus rest of the world), $K=34$ industries and $O=2$ ownership status (domestic-owned firms and foreign-owned firms). Each table (for a separate year between 2005 and 2015) can be split into: $Z_{N K O, N K O}$ a square matrix of intermediate inputs; $Y_{N K O, N}$ a matrix of final demand; $v_{N K O}$ a vector of gross value added; and $x_{N K O}$ a vector of gross output. Using the data described in Annex A, the gross value added (GVA) vector can be replaced by its subcomponents: tax minus subsidies on products, labour compensation, income to tangible capital and income to intangible capital.

The decomposition of factor income along the value chain requires the following intermediary steps ${ }^{1}$. First, we calculate the technical coefficients matrix $A=Z * \widehat{x^{-1}}$; this matrix can be further decomposed into domestic coefficients $A^{D}$ corresponding to the block diagonal of size $K O$ of $\mathrm{A}$ and foreign coefficients $A^{F}$ corresponding to the off-block diagonal. Also, we sum over columns of the final demand matrix to get the final demand vector $y=Y * u_{N}^{\prime}$ where $u$ is a vector with all elements equal to one. We note $B$ (respectively $B^{D}$ ) the Leontief matrix of the technical coefficient matrix $A\left(A^{D}\right)$ calculated as $B=(I-A)^{-1}$ where $\mathrm{I}$ is the identity matrix.

We can decompose the GVA into purely domestic production and an international production part irrespective of where final consumption takes place (either abroad or at home).

$$
\begin{array}{cl}
G V A= & \hat{v} * x \\
x= & A * x+y \\
& \left(A^{D}+A^{F}\right) * x+y \\
& B^{D} * y+B^{D} * A^{F} * B * y \\
G V A= & \hat{v} * B^{D} * y+\hat{v} * B^{D} * A^{F} * B * y
\end{array}
$$

The first part of (B.4) $\hat{v} * B^{D} * y$ corresponds to the purely domestic production: inputs are not sent for processing abroad while the second part $\hat{v} * B^{D} * A^{F} * B * y$ corresponds to international production.

We thus obtain the gross value added at basic price split between pure domestic production and international production. However, we want to reallocate the trade margin that is included in the wholesale and retail trade sector to the industry of origin. We calculate $y^{\text {margin }}=y *$ trade $\overline{\text { marg }}$ in share and replace $y$ by $y^{\text {margin }}$ in (B.4). This gives us the purely domestic and international production revenues from trade margins that we can reallocate to the non-trade sectors.

The same calculation is then used replacing GVA with the share of gross value added going to intangible capital in order to split returns to intangible capital between domestic-owned firms and foreign-owned firms. 


\section{Endnotes Appendix B} ${ }^{1}$ In the following equations, a hat is used for the diagonal matrix of a vector, upper case letters
indicate matrices and lower case letters vectors. 